NATURAL GROUND-WATER

QUALITY IN MICHIGAN, 1974-87

By T. Ray Cummings

U.S. GEOLOGICAL SURVEY

Open-File Report 89-259

Prepared in cooperation with the

MICHIGAN DEPARTMENT OF NATURAL RESOURCES

GEOLOGICAL SURVEY DIVISION

Lansing, Michigan

July 1989 
DEPARTMENT OF THE INTERIOR

MANUEL LUJAN, JR., Secretary

U.S . GEOLOGICAL SURVEY

Dallas L. Peck, Director

For additional information write to:

District Chief

U.S. Geological Survey 6520 Mercantile Way, Suite 5

Lansing, Michigan 48911
Copies of this report can be purchased from:

U.S. Geological Survey Books and Open-File Reports Section Federal Center, Building 810 Box 25425

Denver, Colorado 80225 
Abst ract---1-0-1

Introduction--

Purpose and scope----1- 2

Methods of investigation-

General water-quality conditions- 3

Areal variations in water quality- 12

Relation of water quality to geologic source-- 17

Relation of water quality to mineral associations--- 25

Conclusions-- 28

Selected references--1 30

Definition of terms- 32

Appendix: Median values of chemical and physical characteristics of water from geologic sources- 33 


\section{ILLUSTRATIONS}

Page

Figure 1. Relation of dissolved-solids concentration to chemical characteristics of water-a

2. Relation of specific conductance to dissolved-solids concentration of water- 7

3. Areal variation of dissolved solids in water---_--- 13

4. Areal variation of ammonia and hardness of water------- 14

5. Areal variation of total recoverable lead and total recoverable mercury in water-

6. Areal variation of total recoverable iron and total recoverable copper in water-16

7. Relation of depth of well to dissolved-solids concentration-_- 18

8. Chemical characteristics of water from glacial deposits- 20

9. Chemical characteristics of water from bedrock (Mississippian, Devonian, and Silurian ages)-..........- 21

10. Chemical characteristics of water from bedrock

(Silurian, Ordovician, Cambrian, and Precambrian ages)--- 22

11. Chemical characteristics of water from bedrock

(Pennsylvanian age)

12. Relation of boron and sodium to geologic source-_-n-.-- 24

13. Relation of titanium to aluminum in water-a 26

14. Relation of zirconium to aluminum in water-a 27

15. Relation of strontium to magnesium in water-a. 29 


\section{TABLES}

Page

Table 1. Maximum and minimum values of chemical and physical

characteristics of ground water-

2. Frequency data for chemical and physical characteristics of ground water- 9

3. Comparison of natural water quality to drinking water regulations of the U.S. Environmental Protection Agency--- 11

4. Comparison of chemical and physical characteristics of water from glacial and bedrock deposits- 19 


\section{CONVERSION FACTORS}

Inch-pound units can be converted to metric (International System) units as follows:

Multiply inch-pound unit

By

To obtain metric unit

foot ( $f t)$

inch (in)

mile (mi)

pound (1b)

$\begin{array}{rl} & 0.3048 \\ & 2.54 \\ 1 & .609 \\ 453.6\end{array}$

meter (m)

centimeter $(\mathrm{cm})$

kilometer $(\mathrm{km})$

gram $(g)$

Temperature

Degrees Fahrenheit $\left({ }^{\circ} \mathrm{F}\right)$ can be converted to degrees Celsius $\left({ }^{\circ} \mathrm{C}\right)$ by the following formula:

$$
{ }^{\circ} \mathrm{C}=\left({ }^{\circ} \mathrm{F}-32\right) 11.8
$$




\title{
NATURAL GROUND-WATER QUALITY \\ IN MICHIGAN, 1974-87
}

by T. Ray Cummings

\begin{abstract}
Wide variations occur in the chemical and physical characteristics of natural ground waters in Michigan. Dissolved-solids concentrations range from 20 to $76,000 \mathrm{milligrams}$ per liter. Waters having low dissolved-solids concentrations are calcium bicarbonate-type waters. Sodium, sulfate, and chloride concentrations increase as mineralization increases. Iron, aluminum, and titanium concentrations are higher at some locations than is common in most natural waters. Lead concentrations exceed those considered suitable for drinking water at some locations in the northern part of the Lower Peninsula. Generalized areal patterns of water quality variation indicate that geology is a primary cause of differences across the state. Examples of chemical associations in water indicate that chemical analyses may be valuable in tracing and identifying mineral deposits.
\end{abstract}

\section{INTRODUCTION}

Information on the natural ${ }^{1}$ chemical and physical characteristics of ground water, particularly with respect to substances that occur in trace amounts, does not meet needs in Michigan and in other parts of the nation. Such information is essential for establishing baseline conditions against which long-term changes in water quality can be judged, and for properly evaluating the degree and severity of contamination when it occurs. In addition to supporting management decisions relating to the protection of the water resource, a better definition of natural water quality is necessary for studies of the significance and relation of the geochemical environment to human health and disease. Water-quality information is also important in the identification and development of mineral resources. As economically important minerals become scarce, and as their value increases, chemical analyses of ground water will likely be used even more frequently for this purpose.

In 1974, the Geological Survey Division of the Michigan Department of Natural Resources and the U.S. Geological Survey began a cooperative program to investigate the natural characteristics of water in aquifers in the State. The program is a continuing one in which carefully selected wells are sampled each year. New wells are also drilled to the principal aquifers to monitor both water quality and water levels. The design and construction of these wells is such that they are suitable as long-term observation sites. Site selection is made in all cases so as to avoid known, or even suspected, contamination. Seventeen new wells have been installed specifically for the investigation. Since 1974, 210 wells have been sampled. Information obtained through this program is the basis of this report.

1 The term "natural" is used to characterize water exhibiting no readily detectable modification by human activity. It is probable that few, if any, of the ground waters normally sought as supplies are completely free of all cultural influence. 


\section{Purpose and Scope}

This report updates a preliminary report on chemical and physical characteristics of natural ground waters in Michigan (Cummings, 1980). Al though substantial amounts of information have been collected since 1980 , definitive statements about waters from many sources and at many locations remain impossible. Interpretations are thus intended to illustrate the direction that studies might take as information accumulates from the continuing program. For this study, maximum and minimum values of individual substances and properties have been determined, as well as how frequently values of a given magnitude may be expected. Water-quality characteristics have been related to geologic source, areal variations identified if possible, and geochemical associations noted. Chemical analyses from other data programs or sources have not been used in this evaluation, largely because it seemed preferable to confine the study to data collected using uniform procedures and techniques, and because no prior analyses for some substances are available.

\section{Methods of Investigation}

In conjunction with the Michigan Geological Survey, available information on wells was reviewed each year to select possible wells for sampling. Geologic source, well location, and the probability of obtaining representative water from an aquifer were considered in the selection. Wells were pumped from $1 / 2$ to $1-1 / 2$ hours before sample collection. While at the well site, specific conductance, $\mathrm{pH}$, and temperature were measured. Filtration, treatment, or chilling was also done at the site, as appropriate.

Laboratory analyses of 86 substances or properties generally were made. The major anions and cations, trace metals, pesticides, and other substances of particular significance were included in analytical work. Analyses for bismuth, gallium, germanium, tin, titanium, and zirconium where deleted from the analytical scheme when laboratory costs became prohibitive in 1980 . Three hundred eight samples were collected, 98 of which were collected when wells were resampled. The second sample was obtained from some wells when the results of analysis was questionable, or to confirm an unusual quality characteristic. Other wells have been resampled at 5 -year intervals to monitor changes in water quality. Analyses of water from nine wells have not been used in this study because, in the author's judgment, modification of natural water quality is detectable. If trace amounts of pesticides were detected, the entire analysis was eliminated from the data. This occurred in seven instances. In tabulating maximum and minumum values, 299 analyses have been used. For all other evaluations of data, only one analysis of water from a well has been used to prevent distortions in mean, median, and frequency computations. Thus, most conclusions are based on analyses of 201 samples. Complete chemical analyses of water from each well and exact well locations have been published in annual reports by Huffman (1979a,b, $1980,1981,1982,1983,1984,1985,1986,1988)$ and by Huffman and Whited (1988). These reports, available from the U.S. Geological Survey in Lansing, may be inspected for more complete and specific information. A description of 1 aboratory methods used by the U.S. Geological Survey in the analysis of samples is given in Barnett and Mallory (1971), Fishman and 
Friedman (1985), Thatcher and others (1977), Friedman and Erdmann (1982), and Wershaw and others (1983).

Samples were obtained from wells in 77 of Michigan's 83 counties at locations distributed throughout the state. Geologically, water samples were obtained from 45 different glacial and bedrock deposits. (See Appendix.) If no firm characterization of the composition or texture of glacial deposits could be made, the source of water has been identified as "Glacial deposits, undifferentiated."

\section{GENERAL WATER-QUALITY CONDITIONS}

Considerable variation occurs in the quality of ground water from place to place throughout the State. Table 1 ists the maximum and minimum values for all substances and properties other than pesticides. Maximum and minimum dissolved-solids concentrations differ by a factor of about 3,0004,000 , due to the occurrence of natural brines at some locations. The concentrations of most individual substances are within the range common for ground waters, with the exception of those of iron, aluminum, and titanium. The maximum concentrations of each were: iron, 150,000 $\mathrm{\mu g} / \mathrm{L}$ (micrograms per liter); aluminum, 44,000 $\mu \mathrm{g} / \mathrm{L}$; and titanium, 3,600 $\mathrm{\mu g} / \mathrm{L}$.

Waters having a low dissolved-solids concentration generally are calcium bicarbonate-type waters--that is, the calcium constitutes more than 50 percent of the cations and bicarbonate constitutes more than 50 percent of the anions. As the dissolved-solids concentration of a typical water increases, the proportion of sodium, sulfate, and chloride increases. Figure 1 illustrates generalized changes in chemical composition as dissolved-solids increases from 100 to about $2,000 \mathrm{mg} / \mathrm{L}$ (milligrams per liter).

Sulfate and chloride increase most rapidly as dissolved solids increase, accompanied by a proportional decrease in bicarbonate. A decrease in calcium is balanced by a corresponding increase in sodium. Magnesium does not change appreciably. Natural brines are predominately sodium chloride-type waters.

In general, the concentrations of major dissolved substances increase as dissolved solids increase. Concentrations of most trace substances, however, seem to be unrelated to the dissolved-solids concentration of the water. For example, no correlation was detected between dissolved-solids concentration and aluminum, barium, boron, cadmium, chromium, copper, iron, lead, manganese, nitrogen, silica, titanium, vanadium, uranium, or zinc when the dissolved-solids concentration was 1 ess than $2,000 \mathrm{mg} / \mathrm{L}$. Strontium, an exception, does increase as dissolved solids increase. Brines, however, commonly have higher concentrations of most trace substances.

Specific conductance, which is a measure of the ability of water to conduct an electrical current, is frequently used to estimate dissolvedsolids concentration. The relation of dissolved solids to specific conductance is determined by the amount and type of substances in solution. Generally, water composed predominately of divalent ions will have a dissolved solids-specific conductance ratio greater than a water composed predominately of univalent ions. Figure 2 shows the relation of specific conductance and dissolved-solids concentration based on samples collected for this study.

Polychlorinated biphenyls, polychlorinated napthalenes, and 24 pesticides were determined on each sample. Analyses were made for each 
Table 1.--Maximum and minimum values of chemical and physical characteristics of ground water

[mg/L is milligrams per liter. $\mu g / \mathrm{L}$ is micrograms per liter. $<$ means less than]

\begin{tabular}{|c|c|c|}
\hline Constituent or property & Maximum & Minimum \\
\hline Alkalinity (mg/L as $\left.\mathrm{CaCO}_{3}\right)$ & 484 & 7 \\
\hline Aluminum, total recoverable $(\mu \mathrm{g} / \mathrm{L}$ as $\mathrm{Al})$ & 44,000 & $<10$ \\
\hline Arsenic, total $(\mu g / L$ as $A s)$ & 61 & 0 \\
\hline Barium, total recoverable $(\mu g / L$ as $B a)$ & 4,100 & 8 \\
\hline Beryllium, total recoverable $(\mu g / L$ as $B e)$ & 30 & 0 \\
\hline Bicarbonate $\left(\mathrm{mg} / \mathrm{L}\right.$ as $\left.\mathrm{HCO}_{3}\right)$ & 590 & 8 \\
\hline Bismuth, total $(\mu \mathrm{g} / \mathrm{L}$ as $\mathrm{Bi})$ & $<40$ & $<1$ \\
\hline Boron, total recoverable $(\mu \mathrm{g} / \mathrm{L}$ as $\mathrm{B})$ & 2,800 & 0 \\
\hline Cadmium, total recoverable $(\mu \mathrm{g} / \mathrm{L}$ as $\mathrm{Cd})$ & 21 & 0 \\
\hline Calcium, dissolved (mg $/ \mathrm{L}$ as $\mathrm{Ca}$ ) & 1,300 & 2.4 \\
\hline Carbon, organic dissolved ( $\mathrm{mg} / \mathrm{L}$ as $\mathrm{C}$ ) & 28 & $<.1$ \\
\hline Cârbon dioxide, dissolved (mg/L as $\left.\mathrm{CO}_{2}\right)$ & 187 & $<.1$ \\
\hline Carbonate $\left(\mathrm{mg} / \mathrm{L}\right.$ as $\left.\mathrm{CO}_{3}\right)$ & 24 & 0 \\
\hline Chloride, dissolved ( $\mathrm{mg} / \mathrm{L}$ as $\mathrm{Cl}$ ) & 50,000 & .4 \\
\hline Chromium, total recoverable $(\mu \mathrm{g} / \mathrm{L}$ as $\mathrm{Cr})$ & 180 & 0 \\
\hline Cobalt, total recoverable $(\mu g / L$ as Co $)$ & 50 & 0 \\
\hline Color (platinum cobalt units) & 500 & 0 \\
\hline Copper, total recoverable ( $\mu \mathrm{g} / \mathrm{L}$ as $\mathrm{Cu})$ & 1,900 & 0 \\
\hline Cyanide, total (mg/L as $\mathrm{CN})$ & .06 & .00 \\
\hline Fluoride, dissolved ( $\mathrm{mg} / \mathrm{L}$ as $\mathrm{F}$ ) & 2.0 & $<.10$ \\
\hline Gallium, total $(\mu g / L$ as $G a)$ & $<20$ & $<1$ \\
\hline Germanium, total $(\mu \mathrm{g} / \mathrm{L}$ as $\mathrm{Ge})$ & $<50$ & $<1$ \\
\hline Hardness (mg/L as $\mathrm{CaCO}_{3}$ ) & 5,300 & 9 \\
\hline Hardness, noncarbonate (mg/L as $\left.\mathrm{CaCO}_{3}\right)$ & 5,200 & 0 \\
\hline Iron, dissolved $(\mu g / L$ as $F e)$ & 23,000 & 0 \\
\hline Iron, total recoverable $(\mu \mathrm{g} / \mathrm{L}$ as $\mathrm{Fe})$ & 150,000 & $<10$ \\
\hline Lead, total recoverable $(\mu g / L$ as $\mathrm{Pb})$ & 500 & 0 \\
\hline Lithium, total recoverable $(\mu \mathrm{g} / \mathrm{L}$ as $\mathrm{Li})$ & 290 & 0 \\
\hline Manganese, dissolved $(\mu g / L$ as $M n)$ & 710 & 0 \\
\hline Manganese, total recoverable $(\mu \mathrm{g} / \mathrm{L}$ as $\mathrm{Mn})$ & 1,100 & 0 \\
\hline Magnesium, dissolved (mg/L as Mg) & 510 & 0.4 \\
\hline Mercury, total recoverable $(\mu \mathrm{g} / \mathrm{L}$ as $\mathrm{Hg})$ & 2.1 & $<.10$ \\
\hline Molybdenum, total recoverable ( $\mu \mathrm{g} / \mathrm{L}$ as Mo) & 40 & 0 \\
\hline $\mathrm{Nickel,} \mathrm{total} \mathrm{recoverable}(\mu \mathrm{g} / \mathrm{L}$ as $\mathrm{Ni})$ & 50 & 0 \\
\hline Nitrogen, total (mg/L as $N)$ & 7.6 & $<.01$ \\
\hline Nitrogen, ammonia, total (mg/L as $\mathrm{N}$ ) & 9.2 & .00 \\
\hline Nitrogen, nitrate, total (mg/L as $N$ ) & 7.0 & .00 \\
\hline Nitrogen, nitrite, total (mg/L as $N)$ & .21 & .00 \\
\hline
\end{tabular}


Table 1.--Maximum and minimum values of chemical and physical characteristics of ground water--Continued

\begin{tabular}{|c|c|c|}
\hline Constituent or property & Maximum & Mininum \\
\hline $\mathrm{Nitrogen}$, organic, total ( $\mathrm{mg} / \mathrm{L}$ as $\mathrm{N}$ ) & 4.5 & 0.00 \\
\hline pH (units) & 9.5 & 6.0 \\
\hline Phenols $(\mu \mathrm{g} / \mathrm{L})$ & 250 & 0 \\
\hline Phosphorus, total (mg/L as $P$ ) & .59 & .00 \\
\hline Phosphorus, or tho, total (mg/L as P) & .46 & .00 \\
\hline Potassium, dissolved (mg/L as $K$ ) & 120 & .1 \\
\hline Selenium, total $(\mu \mathrm{g} / \mathrm{L}$ as $\mathrm{Se})$ & 10 & 0 \\
\hline Silica, dissolved (mg/L as $\mathrm{SiO}_{2}$ ) & 26 & .3 \\
\hline Silver, total recoverable $(\mu g / L$ as $\mathrm{Ag})$ & 13 & 0 \\
\hline Sodium, dissolved (mg/L as Na) & 28,000 & .5 \\
\hline Solids, residue at $180^{\circ} \mathrm{C}$, dissolved $(\mathrm{mg} / \mathrm{L})$ & 76,000 & 20 \\
\hline Solids, sum of constituents, dissolved $(\mathrm{mg} / \mathrm{L})$ & 80,200 & 23 \\
\hline Specific conductance (microsiemens) & 158,000 & 37 \\
\hline Strontium, total recoverable $(\mu \mathrm{g} / \mathrm{L}$ as $\mathrm{Sr})$ & 39,000 & 10 \\
\hline Sulfate, dissolved $\left(\mathrm{mg} / \mathrm{L}\right.$ as $\left.\mathrm{SO}_{4}\right)$ & 1,200 & .7 \\
\hline Temperature $(\operatorname{deg} C)$ & 18.5 & 6.0 \\
\hline Tin, total recoverable $(\mu \mathrm{g} / \mathrm{L}$ as $\mathrm{Sn})$ & $<40$ & $<1$ \\
\hline Titanium, total $(\mu g / L$ as $T i)$ & 3,600 & 0 \\
\hline Tritium, total $(\mathrm{pCi} / \mathrm{L})$ & 470 & 13 \\
\hline Turbidity (FTU) & 220 & .10 \\
\hline Uranium, dissolved, extraction $(\mu g / L$ as $U)$ & 11 & .01 \\
\hline Vanadium, total $(\mu g / L$ as $V)$ & 52 & 0 \\
\hline $\mathrm{zinc}$, total recoverable $(\mu \mathrm{g} / \mathrm{L}$ as $\mathrm{Zn})$ & 47,000 & 0 \\
\hline zirconium, total $(\mu \mathrm{g} / \mathrm{L}$ as $2 \mathrm{r})$ & 80 & $<1$ \\
\hline
\end{tabular}




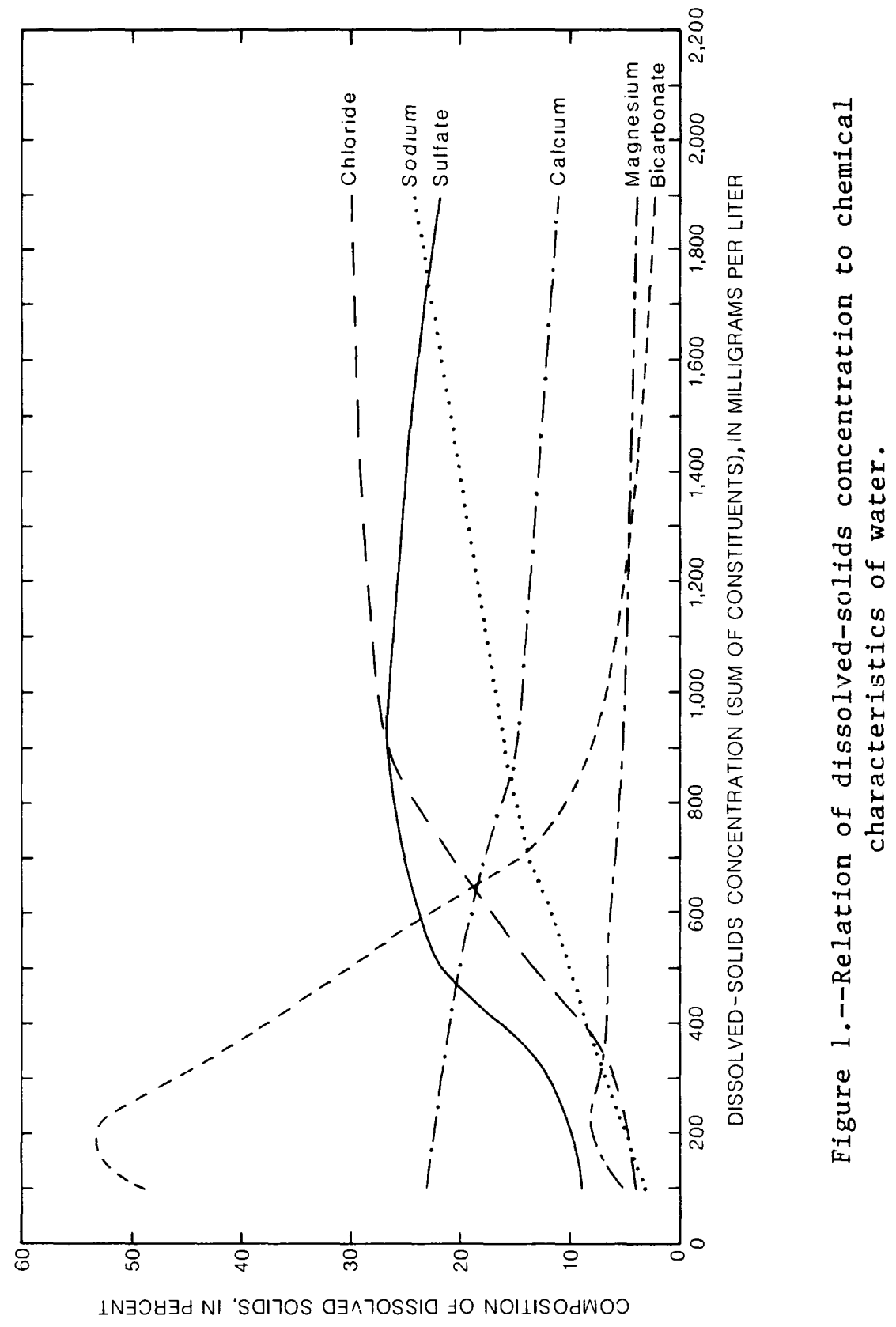




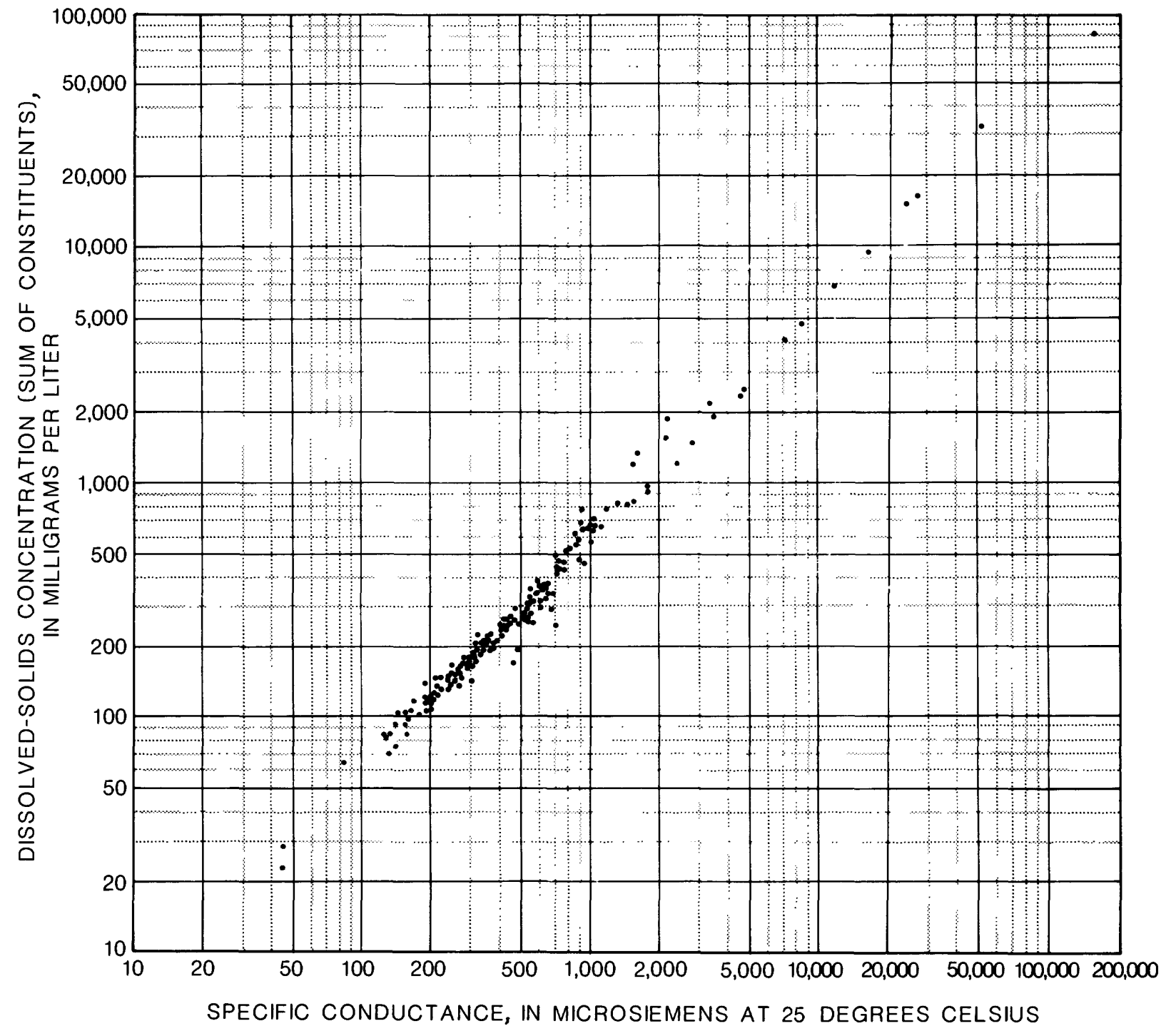

Figure 2.--Relation of specific conductance to dissolved-solids concentration of water. 
of the following substances from 1974 to $1984:^{2}$

$\begin{array}{ll}\text { Aldrin } & \text { Malathion } \\ \text { Chlordane } & \text { Methoxychlor } \\ \text { DDD } & \text { Methyl parathion } \\ \text { DDE } & \text { Methyl trithion } \\ \text { DDT } & \text { Parathion } \\ \text { Diazinon } & \text { Silvex } \\ \text { Dieldrin } & \text { Trithion } \\ \text { Endosulfan } & \text { Toxaphene } \\ \text { Endrin } & 2,4-D \\ \text { Ethion } & 2,4-\text { DP } \\ \text { Heptachlor } & 2,4,5-T \\ \text { Heptachlor epoxide } & \text { Polychlorinated napthalenes } \\ \text { Lindane } & \text { Polychlorinated biphenyls (PCB) }\end{array}$

Pesticides were detected in water from seven wells. Water from these wells contained trace amounts of PCB, DDD, 2,4-D, 2,4-DP, 2,4,5-T, and Diazinon. In most instances, concentrations were less than $0.1 \mu \mathrm{g} / \mathrm{L}$. Resampling and analysis of water from three of the wells showed no detectable pesticide levels. Other chemical characteristics of water from these wells indicated, however, that the water was not representative of natural conditions, and thus the analyses were not included in data summarized in this report.

Frequency distributions showing the percentage of ground waters having a value equal to or less than a specified amount were prepared for most substances and properties. Values occurring at the 10, 25, 50, 75, and 90 percentiles were determined (table 2$).{ }^{3}$ Results indicate how often values of a given magnitude may be expected in uncontaminated ground waters of Michigan, and thus provide a preliminary basis for judging the modification of water-quality characteristics. For example, 10 percent of the chloride concentrations are equal to or less than $0.8 \mathrm{mg} / \mathrm{L} ; 90$ percent of the concentrations are equal to or less than $270 \mathrm{mg} / \mathrm{L}$. Similarly, nitrate, which in high concentration commonly indicates contamination, is equal to or less than $0.59 \mathrm{mg} / \mathrm{L}$ in 90 percent of the waters.

A comparison of frequency data to drinking water regulations of the U.S. Environmental Protection Agency $(1986 a, b)$ is shown in table 3. Both maximum contaminant levels for inorganic chemicals and secondary maximum contaminant levels were referred to frequency curves and the percentage of time the level was equaled or exceeded determined. Lead concentrations exceeded the $50 \mathrm{\mu g} / \mathrm{L}$ maximum contaminant level in 6.9 percent of the ground

2 Beginning in 1985, analyses for 2,4-D, 2,4-DP, 2,4,5-T, and Silvex only were made.

3 Frequency data for some substances are reported as "less than $(<)$ " values. For these substances, low concentrations are reported by the laboratory in a qualitative manner because of the expense of precise quantitive analyses. Frequency distributions prepared for these substances represent a distribution of the most frequently reported "less than" results, and thus values given in table 2 may or may not correspond to concentrations that occur at the indicated frequency. 
Table 2.--Frequency data for chemical and physical characteristics of ground water

[mg/L is milligrams per liter. $\mu \mathrm{g} / \mathrm{L}$ is micrograms per liter. $<$ means less than]

\begin{tabular}{|c|c|c|c|c|c|}
\hline \multirow{2}{*}{ Constituent or property } & \multicolumn{5}{|c|}{$\begin{array}{l}\text { Percent of ground waters having a value equal } \\
\text { to or less than that indicated }\end{array}$} \\
\hline & 10 & 25 & 50 & 75 & 90 \\
\hline Alkalinity ( $\mathrm{mg}, \mathrm{L}^{\prime}$ as $\mathrm{CaCO}_{3}$ ) & 70 & 105 & 155 & 212 & 295 \\
\hline Aluminum, total recoverable $(\mu \mathrm{g} / \mathrm{L}$ as $\mathrm{Al})$ & $<10$ & 10 & 30 & 60 & 220 \\
\hline Arsenic, total $(\mu g / L$ as As) & $<1$ & $<1$ & 1 & 2 & 5 \\
\hline Barium, total recoverable ( $\mu \mathrm{g} / \mathrm{L}$ as $\mathrm{Ba})$ & $<100$ & $<100$ & $<100$ & $<100$ & 100 \\
\hline Beryllium, total recoverable $(\mu \mathrm{g} / \mathrm{L}$ as $\mathrm{Be})$ & $<1$ & $<10$ & $<10$ & $<10$ & $<10$ \\
\hline Bicarbonate (mg/L as $\mathrm{HCO}_{3}$ ) & 90 & 130 & 200 & 270 & 380 \\
\hline Bismuth, total $(\mu \mathrm{g} / \mathrm{L}$ as $\mathrm{Bi})$ & $<1$ & $<2$ & $<4$ & $<7$ & $<17$ \\
\hline Boron, total recoverable $(\mu \mathrm{g} / \mathrm{L}$ as $\mathrm{B})$ & $<10$ & $<10$ & 27 & 140 & 520 \\
\hline Cadmium, total recoverable $(\mu \mathrm{g} / \mathrm{L}$ as $\mathrm{Cd})$ & $<1$ & $<1$ & $<1$ & 1 & 4 \\
\hline Calcium, dissolved (mg/L as Ca) & 22 & 34 & 50 & 75 & 130 \\
\hline Carbon, organic dissolved (mg/L as $\mathrm{C}$ ) & .9 & 1.3 & 2.1 & 3.8 & 6.8 \\
\hline Carbon dioxide, dissolved (mg/L as $\mathrm{CO}_{2}$ ) & 1.2 & 2.5 & 5.6 & 11 & 25 \\
\hline Carbonate $\left(\mathrm{mg} / \mathrm{L}\right.$ as $\left.\mathrm{CO}_{3}\right)$ & 0 & 0 & 0 & 0 & 0 \\
\hline Chloride, dissolved ( $\mathrm{mg} / \mathrm{L}$ as $\mathrm{Cl}$ ) & .8 & 1.3 & 4.4 & 26 & 270 \\
\hline Chromium, total recoverable $(\mu \mathrm{g} / \mathrm{L}$ as $\mathrm{Cr})$ & $<20$ & $<20$ & $<20$ & $<20$ & 20 \\
\hline Cobalt, total recoverable $(\mu \mathrm{g} / \mathrm{L}$ as $\mathrm{Co})$ & $<1$ & $<1$ & $<1$ & 1 & 3 \\
\hline Color (platinum cobalt units) & $<1$ & 1 & 4 & 5 & 10 \\
\hline Copper, total recoverable $(\mu \mathrm{g} / \mathrm{L}$ as $\mathrm{Cu})$ & 1 & 3 & 5 & 12 & 36 \\
\hline Cyanide, total (mg/L as $\mathrm{CN})$ & .00 & .00 & .00 & $<.01$ & $<.01$ \\
\hline Fluoride, dissolved ( $\mathrm{mg} / \mathrm{L}$ as $\mathrm{F}$ ) & $<.1$ & $<.1$ & .1 & .4 & .7 \\
\hline Gallium, total ( $\mu \mathrm{g} / \mathrm{L}$ as $\mathrm{Ga})$ & $<1$ & $<1$ & $<1$ & $<2$ & $<10$ \\
\hline Germanium, total ( $\mu \mathrm{g} / \mathrm{L}$ as $\mathrm{Ge})$ & $<2$ & $<3$ & $<5$ & $<9$ & $<22$ \\
\hline Hardness (mg,/L as $\mathrm{CaCO}_{3}$ ) & 85 & 130 & 200 & 305 & 520 \\
\hline Hardness, noncarbonate ( $\mathrm{mg} / \mathrm{L}$ as $\mathrm{CaCO}_{3}$ ) & 0 & 1 & 12 & 76 & 289 \\
\hline Iron, dissolved $(\mu \mathrm{g} / \mathrm{L}$ as $\mathrm{Fe})$ & 6 & 20 & 90 & 560 & 1,800 \\
\hline Iron, total recoverable $(\mu g / L$ as $F e)$ & 40 & 120 & 560 & 1,700 & 3,700 \\
\hline Lead, total recoverable $(\mu \mathrm{g} / \mathrm{L}$ as $\mathrm{Pb})$ & 1 & 1 & 5 & 13 & 35 \\
\hline Lithium, total recoverable ( $\mu \mathrm{g} / \mathrm{L}$ as $\mathrm{Li})$ & $<10$ & $<10$ & $<10$ & 10 & 40 \\
\hline Manganese, dissolved ( $\mu \mathrm{g} / \mathrm{L}$ as $M n)$ & $<10$ & 3 & 19 & 50 & 130 \\
\hline Manganese, total recoverable ( $\mu$ g/L as $M n)$ & $<10$ & $<10$ & 22 & 86 & 170 \\
\hline Magnesium, dissolved (mg/L as Mg) & 5.8 & 8.8 & 17 & 28 & 46 \\
\hline Mercury, total recoverable $(\mu \mathrm{g} / \mathrm{L}$ as $\mathrm{Hg})$ & $<.50$ & $<.50$ & $<.50$ & $<.50$ & $<.50$ \\
\hline Molybdenum, total recoverable $(\mu \mathrm{g} / \mathrm{L}$ as Mo) & $<1$ & $<1$ & 1 & 3 & 8 \\
\hline Nickel, total recoverable $(\mu \mathrm{g} / \mathrm{L}$ as $\mathrm{Ni})$ & $<1$ & 1 & 2 & 6 & 10 \\
\hline
\end{tabular}


Table 2.--Frequency data for chemical and physical characteristics of ground water--Continued

\begin{tabular}{|c|c|c|c|c|c|}
\hline \multirow{2}{*}{ Constituent or property } & \multicolumn{5}{|c|}{$\begin{array}{l}\text { Percent of ground wa } \\
\text { to or less th }\end{array}$} \\
\hline & 10 & 25 & 50 & 75 & 90 \\
\hline Nitrogen, total (mg/L as $N$ ) & 0.02 & 0.15 & 0.29 & 0.71 & 1.1 \\
\hline Nitrogen, ammonia, total (mg/L as $N$ ) & $<.01$ & $<.01$ & .05 & .19 & .51 \\
\hline Nitrogen, nitrate, total (mg/L as $N$ ) & .00 & .00 & .01 & .13 & .59 \\
\hline Nitrogen, nitrite, total (mg/L as $N$ ) & $<.01$ & $<.01$ & $<.01$ & $<.01$ & .01 \\
\hline Nitrogen, organic, total (mg/L as $N$ ) & .00 & .05 & .13 & .29 & .63 \\
\hline pH (units) & 7.1 & 7.4 & 7.7 & 7.9 & 8.2 \\
\hline Phenols $(\mu g / L)$ & 0 & 0 & $<1$ & 2 & 5 \\
\hline Phosphorus, total (mg/L as P) & $<.01$ & $<.01$ & $<.01$ & .01 & .05 \\
\hline Phosphorus, ortho, total (mg/L as P) & $<.01$ & $<.01$ & $<.01$ & .01 & .02 \\
\hline Potassium, dissolved ( $\mathrm{mg} / \mathrm{L}$ as $\mathrm{K})$ & .5 & .7 & 1.4 & 2.9 & 6.4 \\
\hline Selenium, total $(\mu \mathrm{g} / \mathrm{L}$ as $\mathrm{Se})$ & $<1$ & $<1$ & $<1$ & $<1$ & $<1$ \\
\hline Silica, dissolved (mg/L as $\mathrm{SiO}_{2}$ ) & 5.7 & 7.4 & 11 & 14 & 18 \\
\hline Silver, total recoverable $(\mu g / L$ as $\mathrm{Ag})$ & 0 & $<1$ & $<1$ & $<1$ & $<1$ \\
\hline Sodium, dissolved $(\mathrm{mg} / \mathrm{L}$ as $\mathrm{Na})$ & 1.3 & 2.4 & 6.8 & 27 & 140 \\
\hline Solids, residue at $180^{\circ} \mathrm{C}$, dissolved $(\mathrm{mg} / \mathrm{L})$ & 123 & 159 & 244 & 430 & 1,250 \\
\hline Solids, sum of constituents, dissolved (mg/L) & 114 & 158 & 240 & 378 & 934 \\
\hline Specific conductance (microsiemens) & 191 & 273 & 426 & 709 & 1,610 \\
\hline Strontium, total recoverable $(\mu \mathrm{g} / \mathrm{L}$ as $\mathrm{Sr})$ & 36 & 60 & 150 & 700 & 2,600 \\
\hline Sulfate, dissolved ( $\mathrm{mg} / \mathrm{L}$ as $\mathrm{SO}_{4}$ ) & 4.3 & 7.0 & 13 & 37 & 180 \\
\hline Temperature $(\operatorname{deg} c)$ & 7.5 & 8.0 & 9.5 & 10.5 & 12.0 \\
\hline Tin, total recoverable $(\mu g / L$ as $S n)$ & $<1$ & $<2$ & $<3$ & $<6$ & $<10$ \\
\hline Titanium, total $(\mu \mathrm{g} / \mathrm{L}$ as $\mathrm{Ti})$ & $<1$ & $<2$ & 2 & 10 & 240 \\
\hline Tritium, total $(\mathrm{pCi} / \mathrm{L})$ & $<200$ & $<200$ & $<200$ & $<200$ & $<200$ \\
\hline Turbidity (FTU) & .2 & .3 & 1.5 & 6.4 & 25 \\
\hline Uranium, dissolved, extraction $(\mu \mathrm{g} / \mathrm{L}$ as $U)$ & .00 & .04 & .14 & .32 & .78 \\
\hline Vanadium, total $(\mu g / L$ as $V)$ & 0 & 0 & $<1$ & 4 & 10 \\
\hline 2 inc, total recoverable $(\mu g / L$ as $2 n)$ & $<10$ & 20 & 60 & 290 & 980 \\
\hline Zirconium, total $(\mu \mathrm{g} / \mathrm{L}$ as $2 \mathrm{r})$ & $<2$ & $<3$ & $<5$ & $<10$ & $<30$ \\
\hline
\end{tabular}


Table 3.--Comparison of natural water quality to drinking water regulations of the U.S. Environmental Protection Agency

\begin{tabular}{|c|c|c|c|}
\hline \multirow[b]{2}{*}{ Cont aminant } & \multicolumn{2}{|c|}{$\begin{array}{l}\text { U.S. Environmental Protection Agency } \\
\text { Regulations }(1986 \mathrm{a}, \mathrm{b})\end{array}$} & \multirow{2}{*}{$\begin{array}{c}\text { Natural water quality } \\
\\
\text { Percentage of } \\
\text { values equaling } \\
\text { or exceeding a/ } \\
\text { maximum level }\end{array}$} \\
\hline & $\begin{array}{l}\text { Maximum } \\
\text { contaminant } \\
\text { levels for } \\
\text { inorganic } \\
\text { chemicals }\end{array}$ & $\begin{array}{l}\text { Secondary } \\
\text { maximum } \\
\text { contaminant } \\
\text { levels }\end{array}$ & \\
\hline Arsenic (As) & $50 \mu g / L$ & & 0.5 \\
\hline Barium ( $\mathrm{Ba})$ & $1,000 \mu \mathrm{g} / \mathrm{L}$ & & 1.1 \\
\hline Cadmium (Cd) & $10 \mu \mathrm{g} / \mathrm{L}$ & & 1.6 \\
\hline Chloride $(\mathrm{Cl})$ & & $250 \mathrm{mg} / \mathrm{L}$ & 1.1 \\
\hline Chromium $(\mathrm{Cr})$ & $50 \mu \mathrm{g} / \mathrm{L}$ & & 1.6 \\
\hline Color (units) & & 15 units & 9.4 \\
\hline Copper (Co) & & $1 \mathrm{mg} / \mathrm{L}$ & 0 \\
\hline Fluoride (F) & $4 \mathrm{mg} / \mathrm{L}$ & $2 \mathrm{mg} / \mathrm{L}$ & $\begin{array}{c}0.5 \text { exceed } \\
2.0 \mathrm{mg} / \mathrm{L} ; \text { no } \\
\text { values greater } \\
\text { than } 4.0 \mathrm{mg} / \mathrm{L}\end{array}$ \\
\hline Iron $(\mathrm{Fe})$ & & $300 \mu g / L$ & $\begin{array}{l}34 \text { (dissolved } \mathrm{Fe}) \\
60 \text { (total Fe) }\end{array}$ \\
\hline Lead $(\mathrm{Pb})$ & $50 \mu \mathrm{g} / \mathrm{L}$ & & 6.9 \\
\hline Manganese (Mn) & & $50 \mu \mathrm{g} / \mathrm{L}$ & $\begin{array}{l}22 \text { (dissolved } M n) \\
31 \text { (total Mn) }\end{array}$ \\
\hline Mercury (Hg) & $2 \mu \mathrm{g} / \mathrm{L}$ & & 0.5 \\
\hline Nitrate $\left(\mathrm{NO}_{3}\right.$ as $\left.\mathrm{N}\right)$ & $10 \mathrm{mg} / \mathrm{L}$ & & 0 \\
\hline $\mathrm{pH}$ (units) & & $\begin{array}{l}6.5 \text { to } \\
8.5 \text { units }\end{array}$ & $\begin{array}{l}3.9 \text { exceed } \\
8.5 \text { units; } 1.1 \\
\text { are less than } \\
6.5 \text { units }\end{array}$ \\
\hline Selenium ( Se ) & $10 \mu \mathrm{g} / \mathrm{L}$ & & 0.5 \\
\hline Silver $(A g)$ & $50 \mu \mathrm{g} / \mathrm{L}$ & & 0 \\
\hline Sulfate $\left(\mathrm{SO}_{4}\right)$ & & $250 \mathrm{mg} / \mathrm{L}$ & 4.3 \\
\hline Zinc $(\mathrm{Zn})$ & & $5 \mathrm{mg} / \mathrm{L}$ & 0 \\
\hline Total dissolved sol & lids & $500 \mathrm{mg} / \mathrm{L}$ & 11 \\
\hline
\end{tabular}

a/ Calculation is based only on those waters having a dissolved-solids concentration of $1,000 \mathrm{mg} / \mathrm{L}$ or less. 
waters. Iron and manganese concentrations are frequently greater than secondary maximum levels; total dissolved-solids concentration exceeded the secondary maximum level in 11 percent of the waters. Concentrations of lead, and certainly those of iron and manganese, are likely to decrease if water is treated before use. However, more frequent chemical analyses of lead are desirable when evaluating the suitability of domestic water supplies, particularly in those parts of the State where lead concentrations are highest.

\section{AREAL VARIATIONS IN WATER QUALITY}

Geologic conditions are a principal factor determining the areal variation in quality of ground water throughout the State, although differences may also be due to varying hydrologic conditions. Examples of the areal variation of some water-quality characteristics are shown in figures $3,4,5$, and 6 . Areal patterns were determined by plotting values on maps, and noting areas of similarity. In preparing these figures, only analyses of water containing $2,000 \mathrm{mg} / \mathrm{L}$ or 1 ess of dissolved solids have been used, largely because waters containing greater than $2,000 \mathrm{mg} / \mathrm{L}$ are unlikely to be used as public or domestic supplies. Dissolved-solids concentration of water tend to be highest in the central part of the Lower Peninsula (fig. 3). Many wells in this area obtain water from bedrock deposits, which normally contain more highly mineralized water. The major dissolved substances - calcium, magnesium, sodium, sulfate, and chloride al so tend to be highest in the same area. Hardness ${ }^{4}$ of water is highest in the southeastern part of the State and at some places in the Upper Peninsula (fig. 4.)

Areal variation of ammonia is also illustrated in figure 4. The ammonia concentration of ground water has been of major significance on at least one occasion during the past several years. Plans for a $f$ ish hatchery in southeastern Michigan were abandoned when ground water was found to contain ammonia in excess of that suitable for propagation of trout. Higher ammonia concentrations are 1 ikely in the south-central and southeastern part of the State than at other locations. As information accumulates, more precise delineations of ammonia distribution may provide one of the initial bases for judging the suitability of a ground water for fish hatchery use. Areal variation of mercury and lead is shown in figure 5. Mercury concentrations in ground water are highest in the Upper Peninsula and in the southeastern part of the Lower Peninsula. Geologic conditions in the Upper Penninsula undoubtedly contribute to the higher mercury concentrations in that area. Lead concentrations seem to be highest in the north-central part of the Lower Peninsula, where concentrations frequently approach the maximum permitted in drinking water supplies. Figure 6 shows the areal variation of iron and copper concentrations in ground water throughout the State. Iron

4 The U.S. Geological Survey (Durfor and Becker, 1964) has classified the hardness of water as follows: 0 to $60 \mathrm{mg} / \mathrm{L}$, soft; 61 to $120 \mathrm{mg} / \mathrm{L}$, moderately hard; 121 to $180 \mathrm{mg} / \mathrm{L}$, hard; and $181 \mathrm{mg} / \mathrm{L}$ or greater, very hard. Using this classification, and based on data obtained for this study, 5 percent of the ground waters are soft, 17 percent are moderately hard, 20 percent are hard, and 58 percent are very hard. 


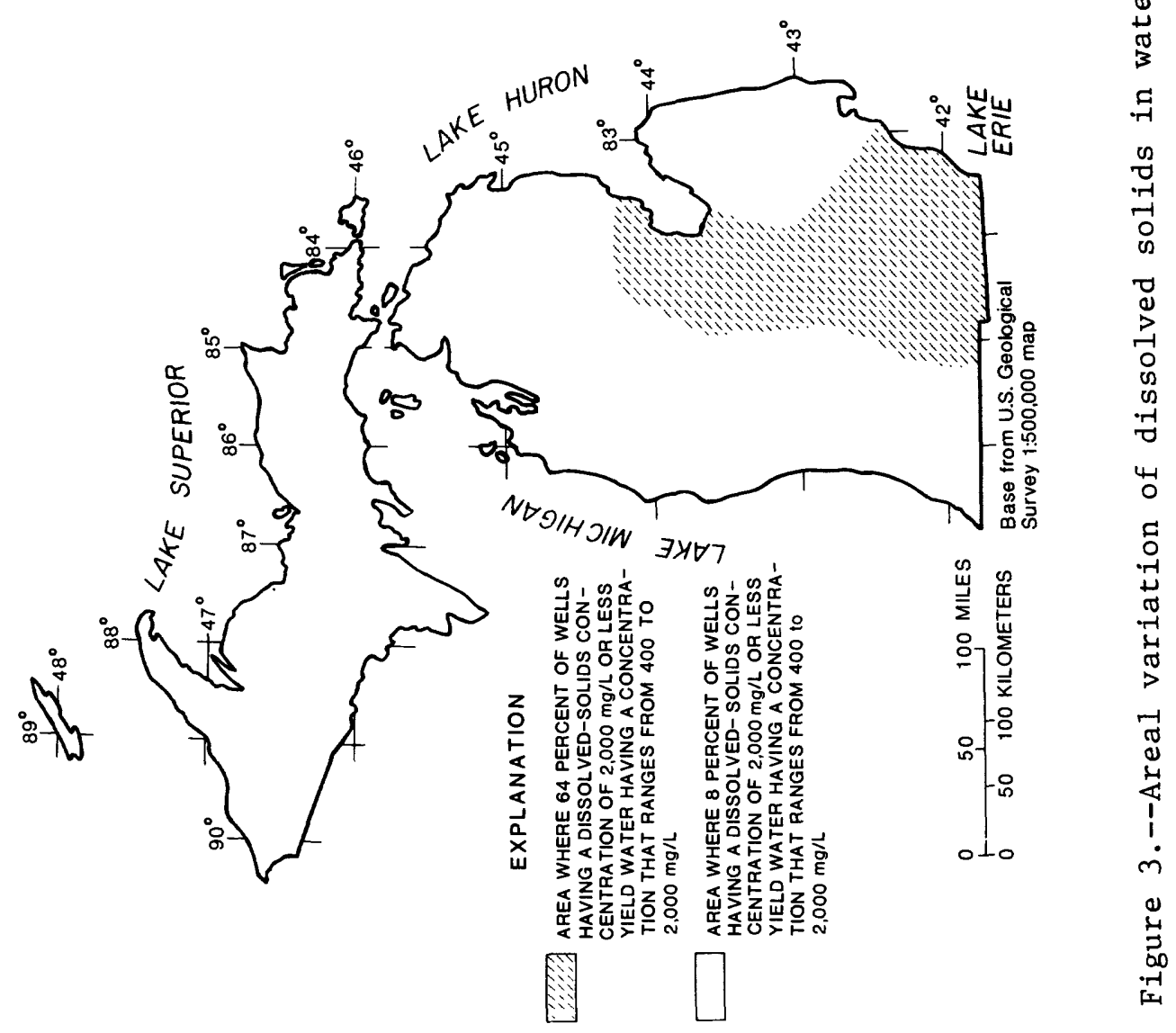



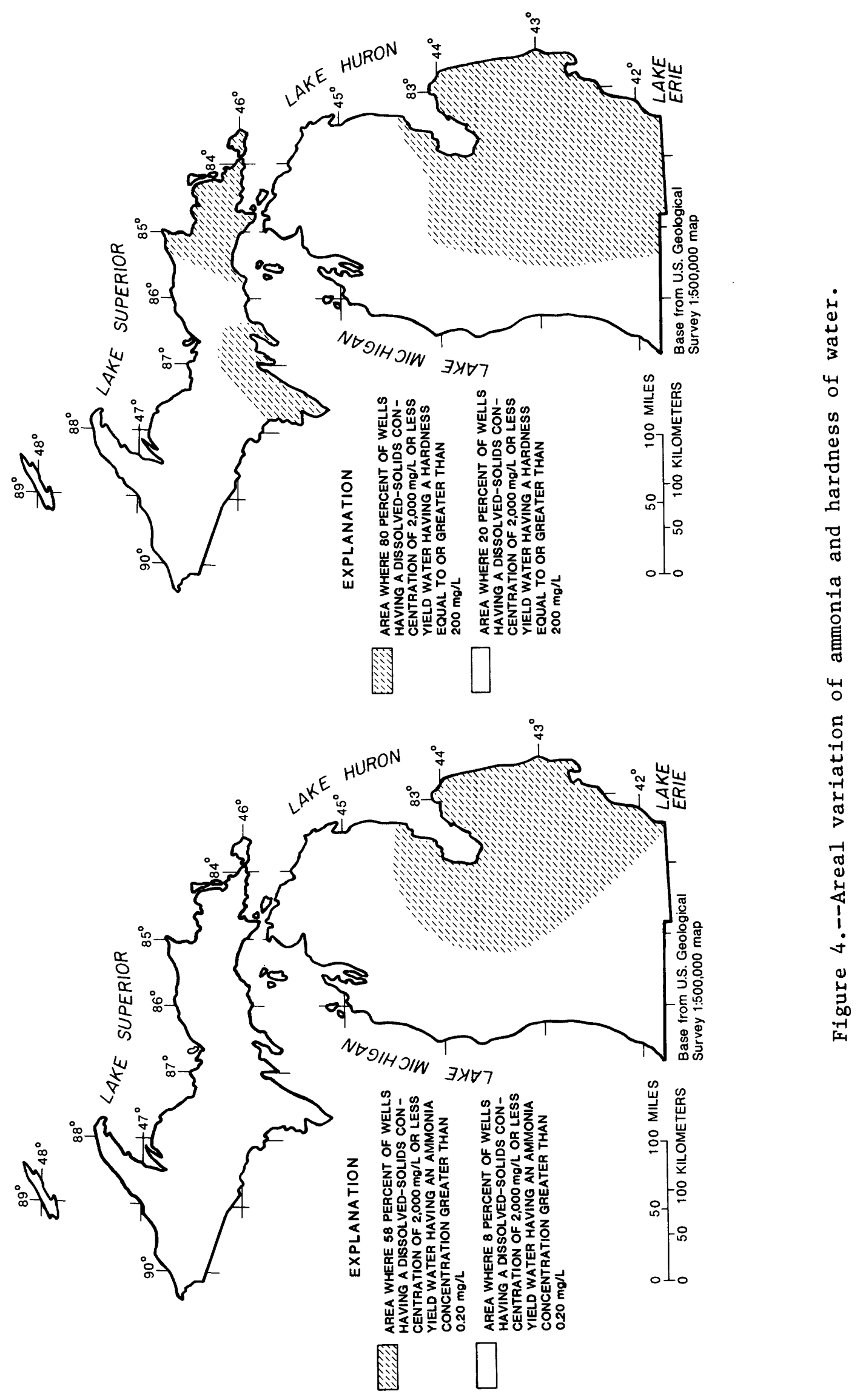

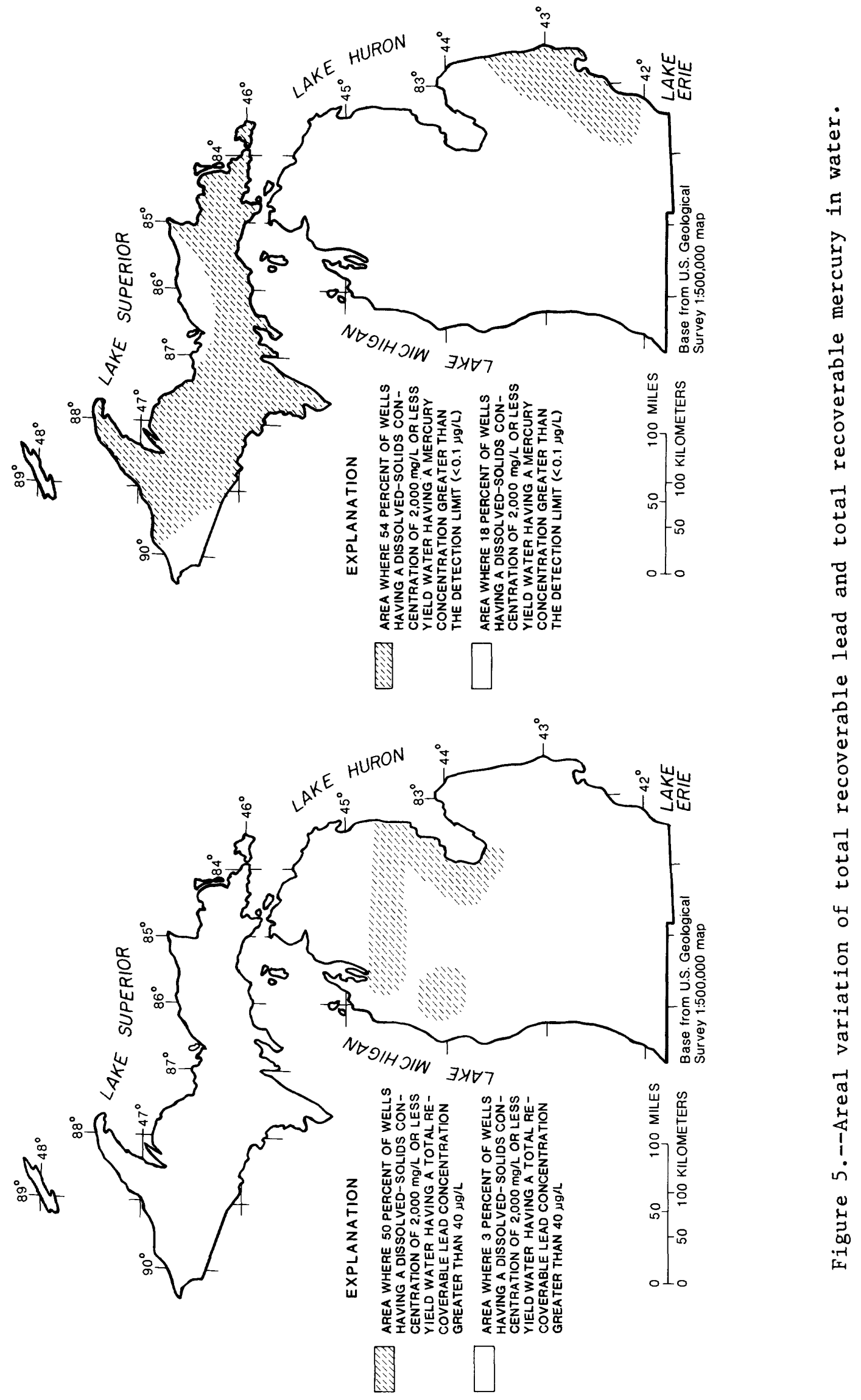

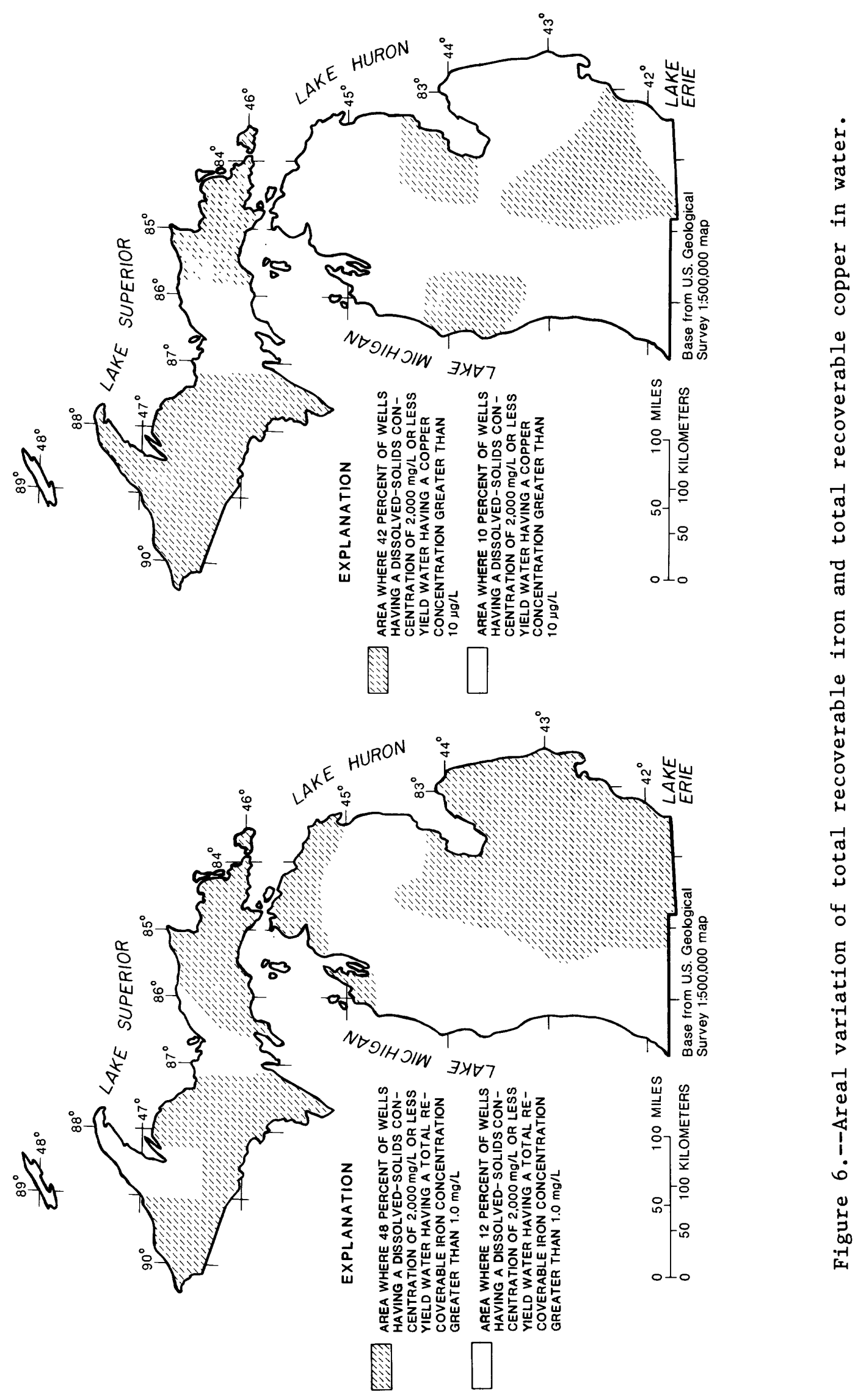
concentrations in most Michigan ground waters is higher than common in many areas of the country; copper concentrations, as might be expected because of the extensive metal deposits, is higher in the Upper Peninsula than in a large part of the Lower Peninsula.

\section{RELATION OF WATER QUALITY TO GEOLOGIC SOURCE}

Chemical analyses were made on water collected from wells tapping 8 glacial deposits ( 103 samples) and 37 bedrock deposits (107 samples). On the basis of 1 ithology, 18 bedrock deposits may be classified primarily as limestone or dolomite, 9 as sandstone, 2 as limestone and sandstone, 2 as conglomerate, 2 as shale, and 1 as sandstone and shale, 2 as metamorphic (slate), and 1 as volcanic. Some of the bedrock deposits, such as the Saginaw Formation, contain sandstone, shale, limestone, and coal. The Appendix 1 ists the median values of each chemical and physical property by geologic source. Interpretations based on the median values should be made with caution because the number of samples of water obtained from each source is different.

The average depth of wells in glacial deposits $95 \mathrm{ft}$ is about a third the average depth of wells in bedrock deposits (253 ft). Although no precise correlation can be demonstrated, the mineralization of water tends to increase as depth of wells increase ( $\mathrm{fig} .7$ ). Highly mineralized water from the Saginaw Formation, however, may occur at depths of less than 200 $\mathrm{ft}$, as figure 7 indicates. The mean dissolved-solids concentration of water from glacial deposits was $266 \mathrm{mg} / \mathrm{L}$; the mean for bedrock deposits was $2,310 \mathrm{mg} / \mathrm{L}$ (table 4). The mean for the Saginaw Formation only is 8,480 $\mathrm{mg} / \mathrm{L}$. Seventy-five percent of the maximum values given in table 1 are associated with water from bedrock deposits.

Figures $8,9,10$, and 11 illustrate the chemical characteristics of water from each geologic source by means of bar diagrams. If sufficitut analyses were available from a geologic source, waters of both high and low mineralization are illustrated.

Among glacial deposits, outwash deposits generally contain water having the highest dissolved-solids concentrations. Higher than average concentrations of some trace metals also occur in water from outwash. For example, water from one well in outwash contained $1,900 \mu \mathrm{g} / \mathrm{L}$ of copper, and another well contained $1,100 \mu \mathrm{g} / \mathrm{L}$ of manganese. Among bedrock deposits, water from the Saginaw Formation was more highly mineralized than that from other bedrock deposits. Some of the maximum concentrations of trace substances also occur in water of the Saginaw Formation. Table 4, which shows mean concentrations for selected substances in water from glacial and bedrock deposits, al so shows mean concentrations computed for outwash deposits and for the Saginaw Formation.

A comparison of water from limestones and dolomites, from sandstones, and from glacial deposits identifed few distinguishing characteristics. For most substances, mean concentrations given in the Appendix do not of fer sufficient evidence to form firm conclusions regarding differences in the water quality of each geologic source. Figure 12 illustrates, however, how boron and sodium are related to lithology. Highest concentrations of each occur in water in the sandstones; lowest concentrations occur in water in glacial deposits and in limestones and dolomites. Areas delineated for each deposit encompass 90 percent or more of the boron and sodium concentrations available for plotting. 


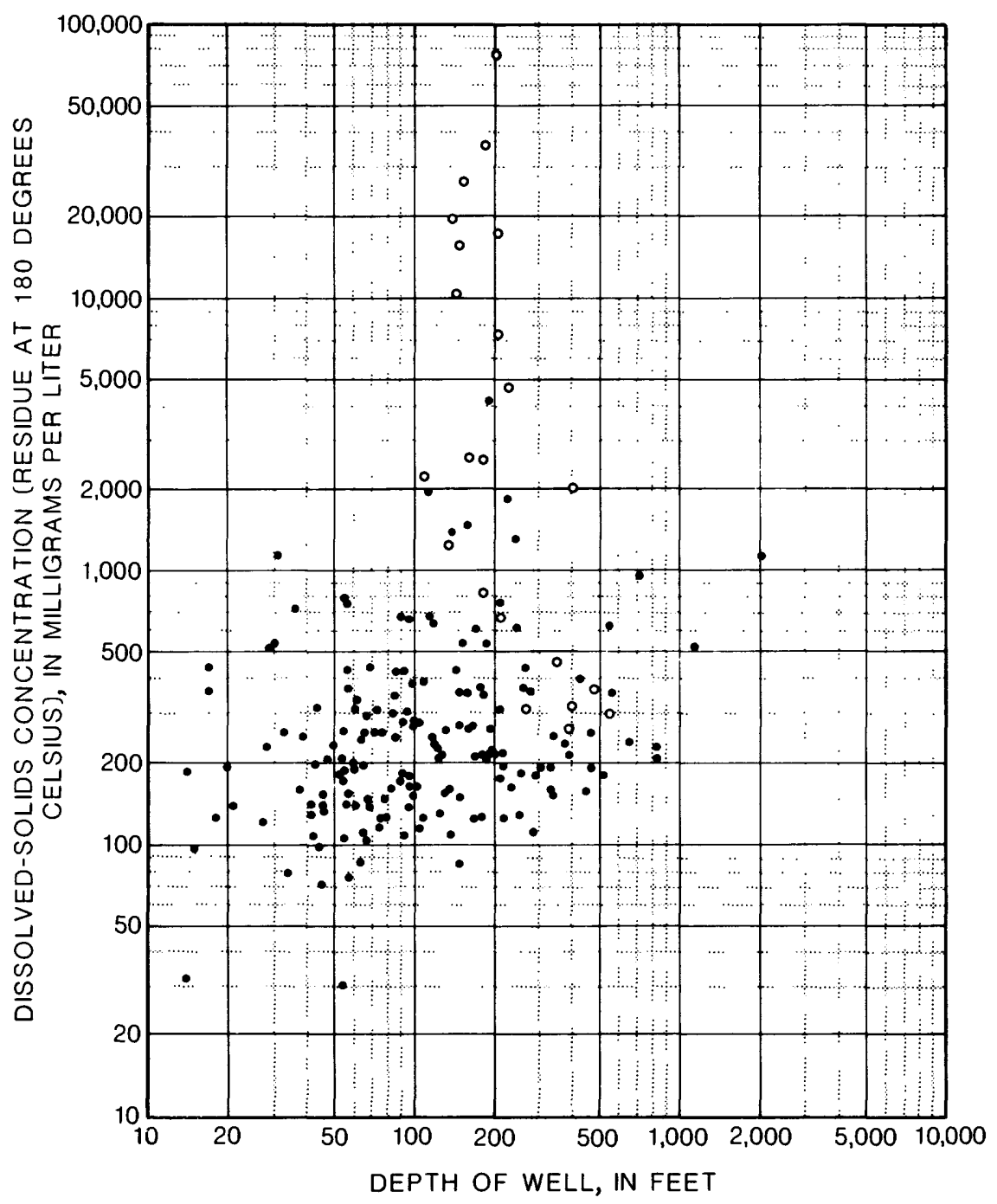

Figure 7.--Relation of depth of well to dissolved-solids concentration. (Open circles indicate Saginaw Formation.) 
Table 4.-- Comparison of chemical and physical characteristics of water from glacial and bedrock deposits

[mg/L is milligrams per liter. $\mu \mathrm{g} / \mathrm{L}$ is micrograms per liter.

$<$ means less than.]

\begin{tabular}{|c|c|c|c|c|}
\hline \multirow{3}{*}{ Constituent } & \multicolumn{4}{|c|}{ Mean concentration } \\
\hline & \multicolumn{2}{|c|}{ Glacial deposits } & \multicolumn{2}{|c|}{ Bedrock deposits } \\
\hline & $\begin{array}{c}\text { A11 } \\
\text { sources }\end{array}$ & $\begin{array}{l}\text { Outwash } \\
\text { only }\end{array}$ & $\begin{array}{c}\text { Al1 } \\
\text { sources }\end{array}$ & $\begin{array}{l}\text { Saginaw } \\
\text { Formation } \\
\text { only }\end{array}$ \\
\hline Al uminum $(\mu \mathrm{g} / \mathrm{L})$ & 184 & 149 & 661 & 2,070 \\
\hline Barium $(\mu g / L)$ & $<100$ & $<100$ & 121 & 350 \\
\hline Boron $(\mu \mathrm{g} / \mathrm{L})$ & 50 & 89 & 288 & 700 \\
\hline Chloride (mg/L) & 26 & 12 & 1,140 & 4,860 \\
\hline Copper $(\mu \mathrm{g} / \mathrm{L})$ & 30 & 102 & 18 & 32 \\
\hline Hardness ( $\mathrm{mg} / \mathrm{L})$ & 197 & 241 & 362 & 780 \\
\hline Iron, total $(\mu g / L)$ & 1,340 & 2,780 & 3,280 & 5,040 \\
\hline Lithium $(\mu g / L)$ & $<10$ & $<10$ & 27 & 64 \\
\hline Manganese, total $(\mu g / L)$ & 68 & 115 & 82 & 165 \\
\hline Nickel $(\mu \mathrm{g} / \mathrm{L})$ & 4.6 & 3.1 & 5.1 & 7.0 \\
\hline Nitrogen, total (mg/L) & .67 & .46 & .84 & 2.0 \\
\hline Potassium (mg/L) & 1.3 & 1.2 & 6.2 & 20 \\
\hline Silica (mg/L) & 11 & 11 & 11 & 9.3 \\
\hline Sodium (mg/L) & 16 & 15 & 662 & 2,840 \\
\hline \multicolumn{5}{|l|}{ Solids (residue), } \\
\hline dissolved $(\mathrm{mg} / \mathrm{L})$ & 266 & 298 & 2,310 & 8,480 \\
\hline St rontium $(\mu \mathrm{g} / \mathrm{L})$ & 285 & 384 & 2,130 & 3,220 \\
\hline Sulfate $(\mathrm{mg} / \mathrm{L})$ & 32 & 68 & 86 & 146 \\
\hline Titanium $(\mu \mathrm{g} / \mathrm{L})$ & 18 & 20 & 310 & 537 \\
\hline $\operatorname{Zinc}(\mu g / L)$ & 225 & 189 & 1,430 & 5,360 \\
\hline
\end{tabular}




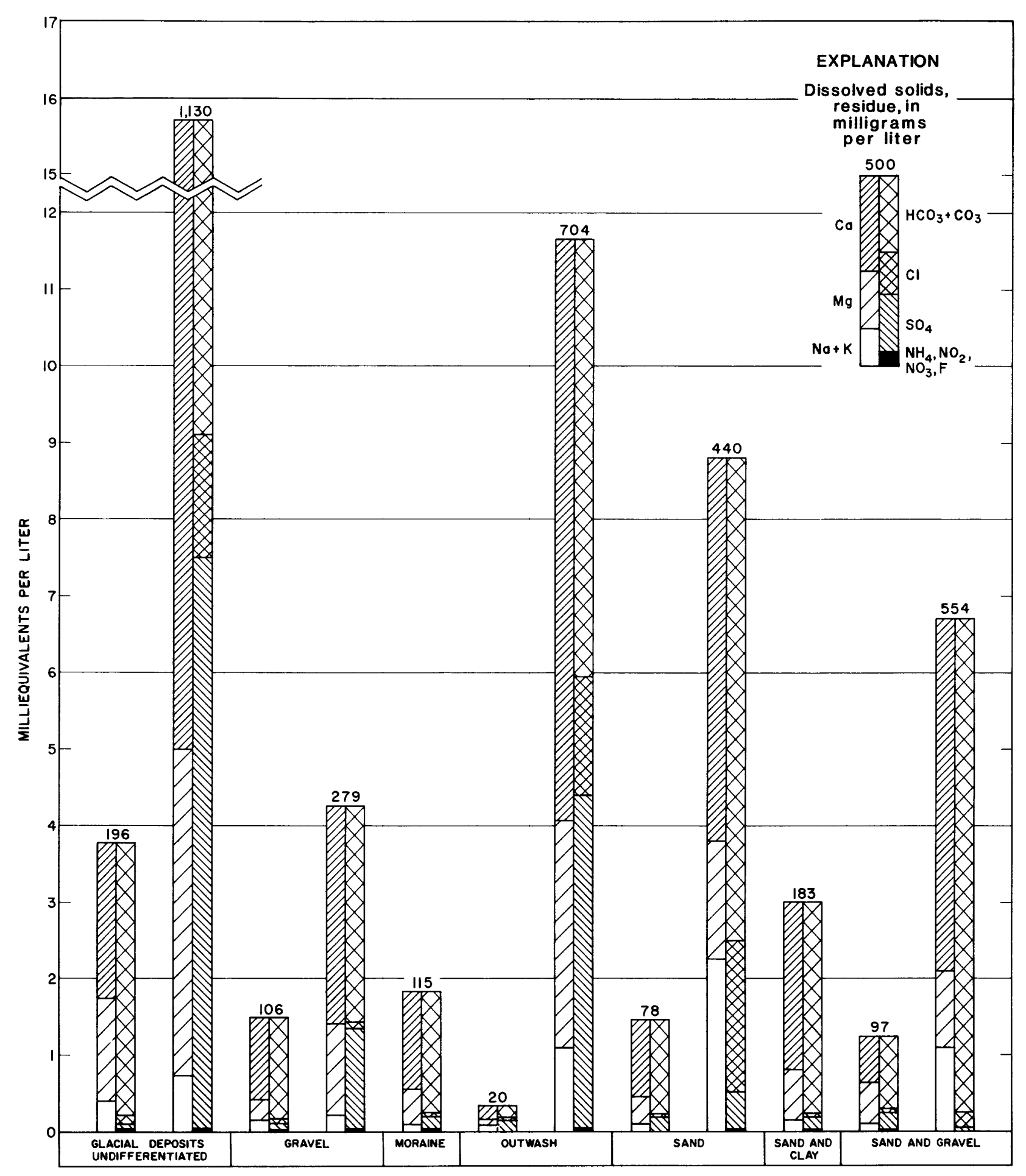

Figure 8.--Chemical characteristics of water from glacial deposits. 


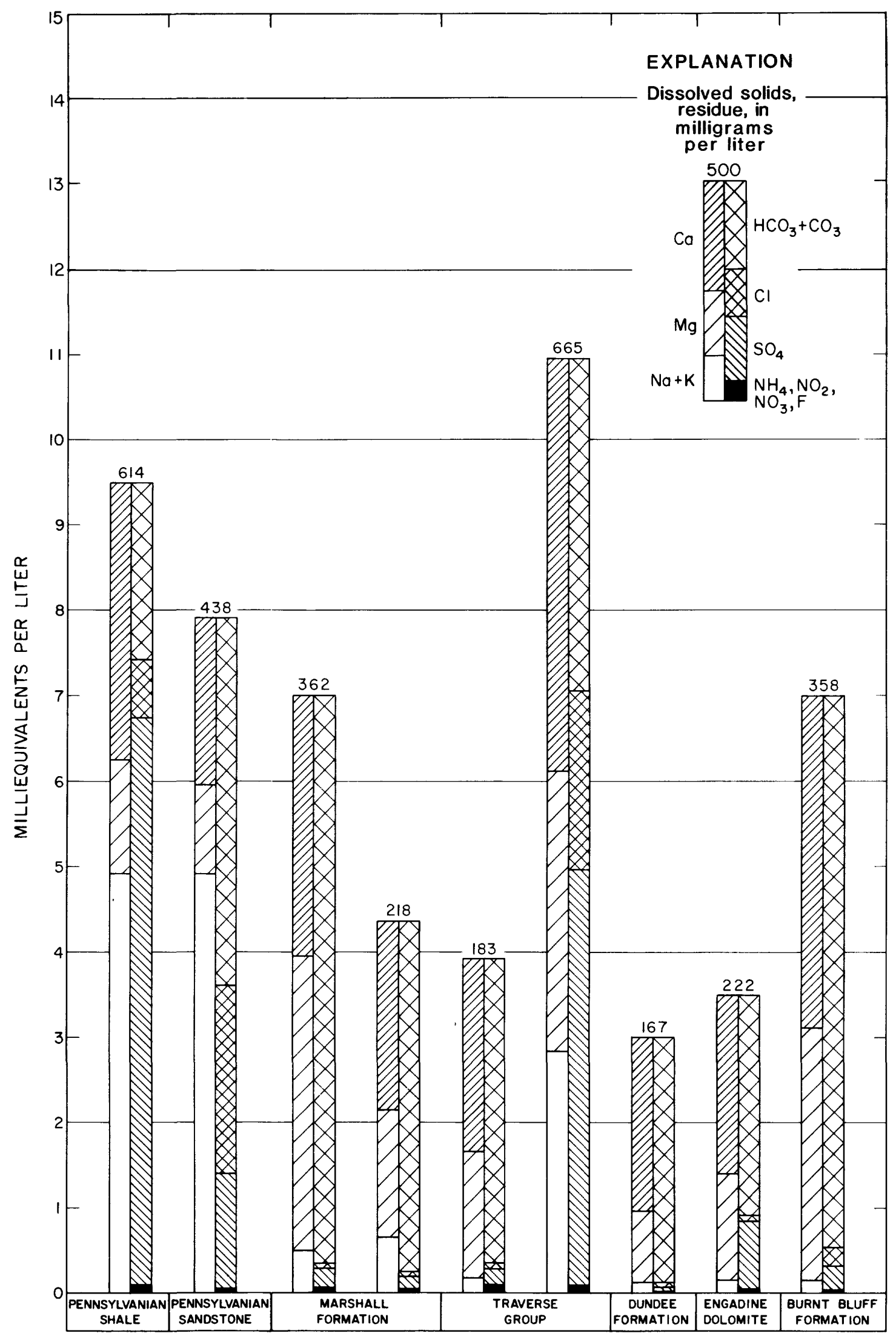

Figure 9.--Chemical characteristics of water from bedrock. (Mississippian, Devonian, and Silurian ages) 


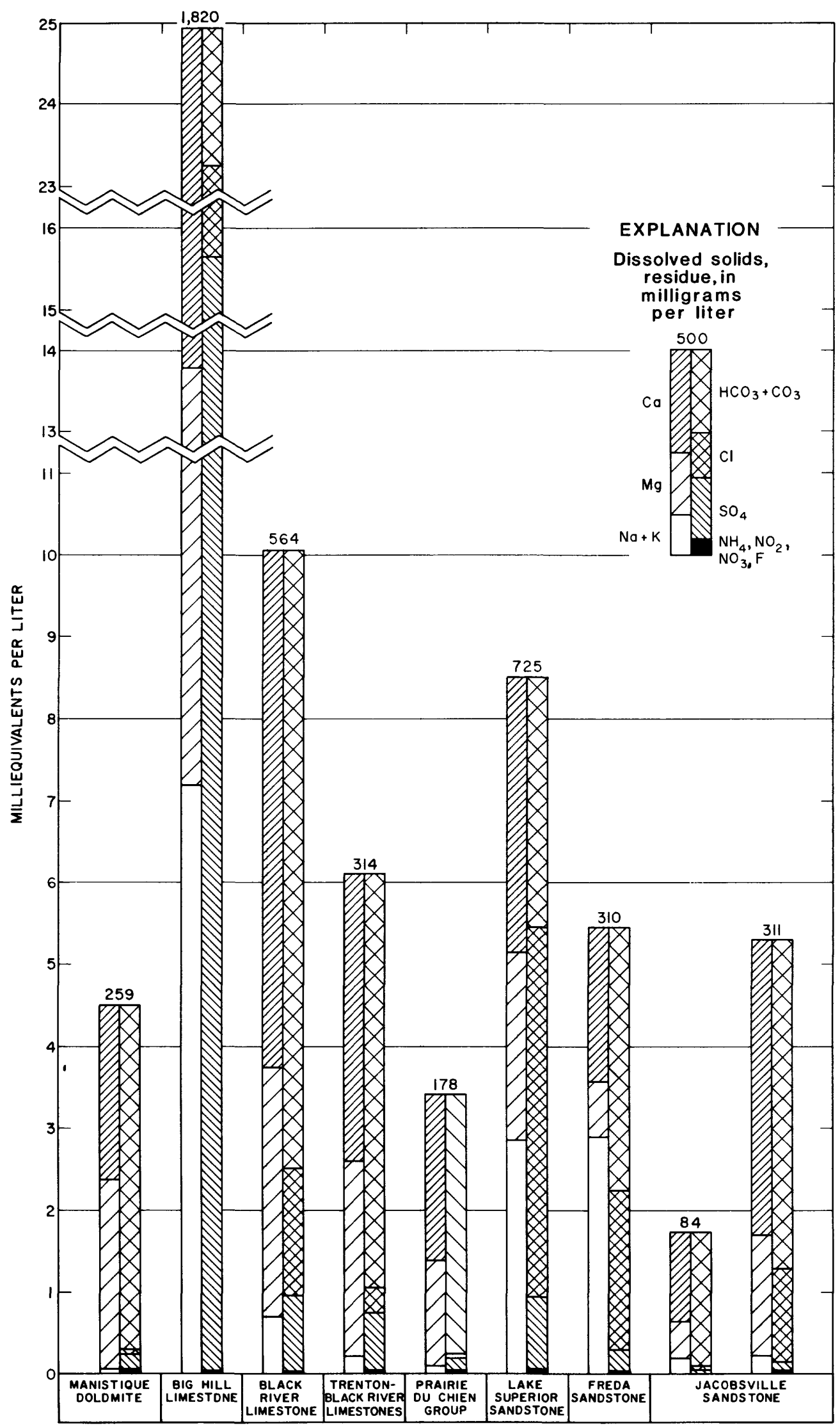

Figure 10.--Chemical characteristics of water from bedrock. (Silurian, Ordovician, Cambrian, and Precambrian ages) 


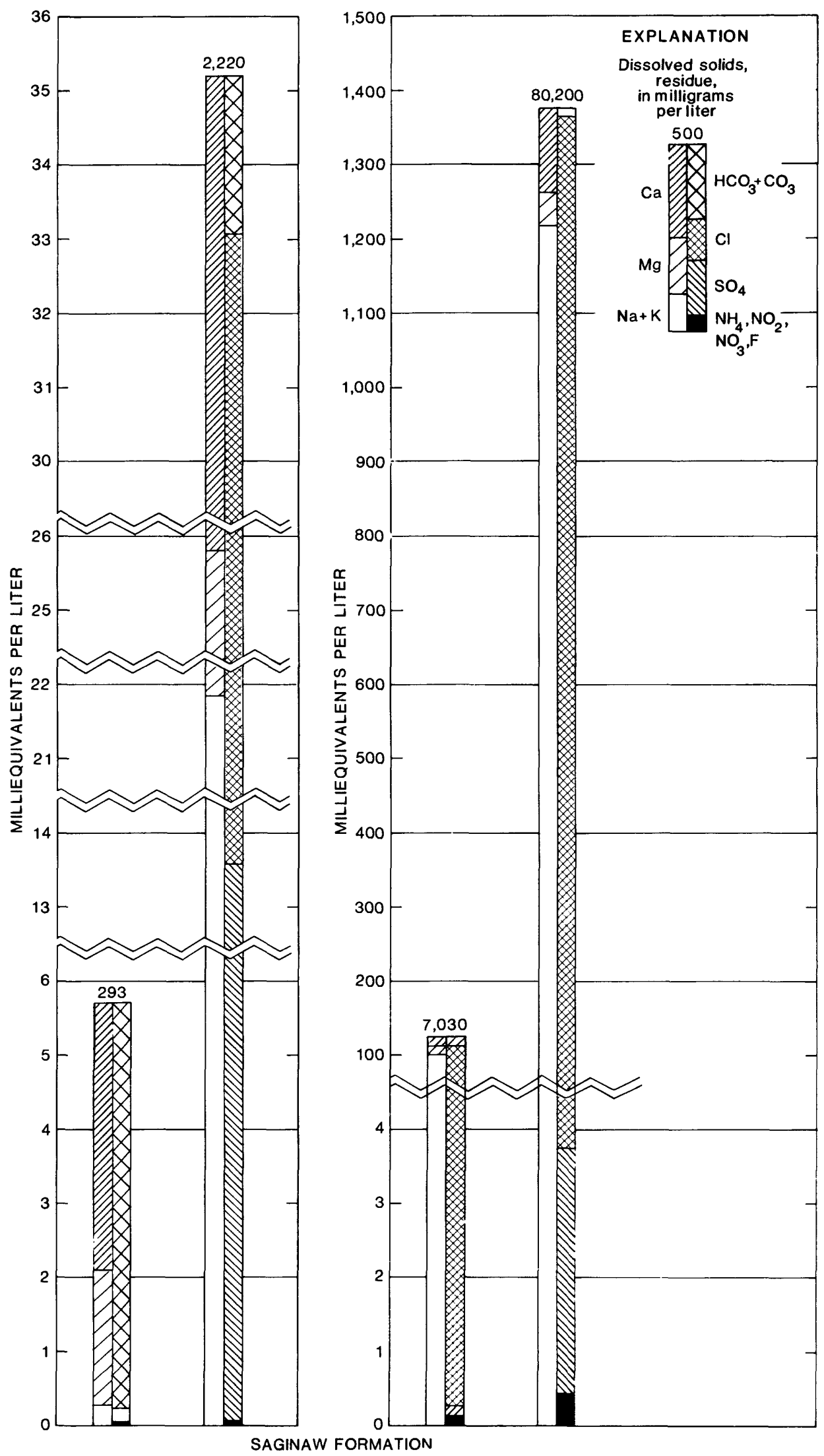

Figure 11.--Chemical characteristics of water from bedrock. (Pennsylvanian age) 


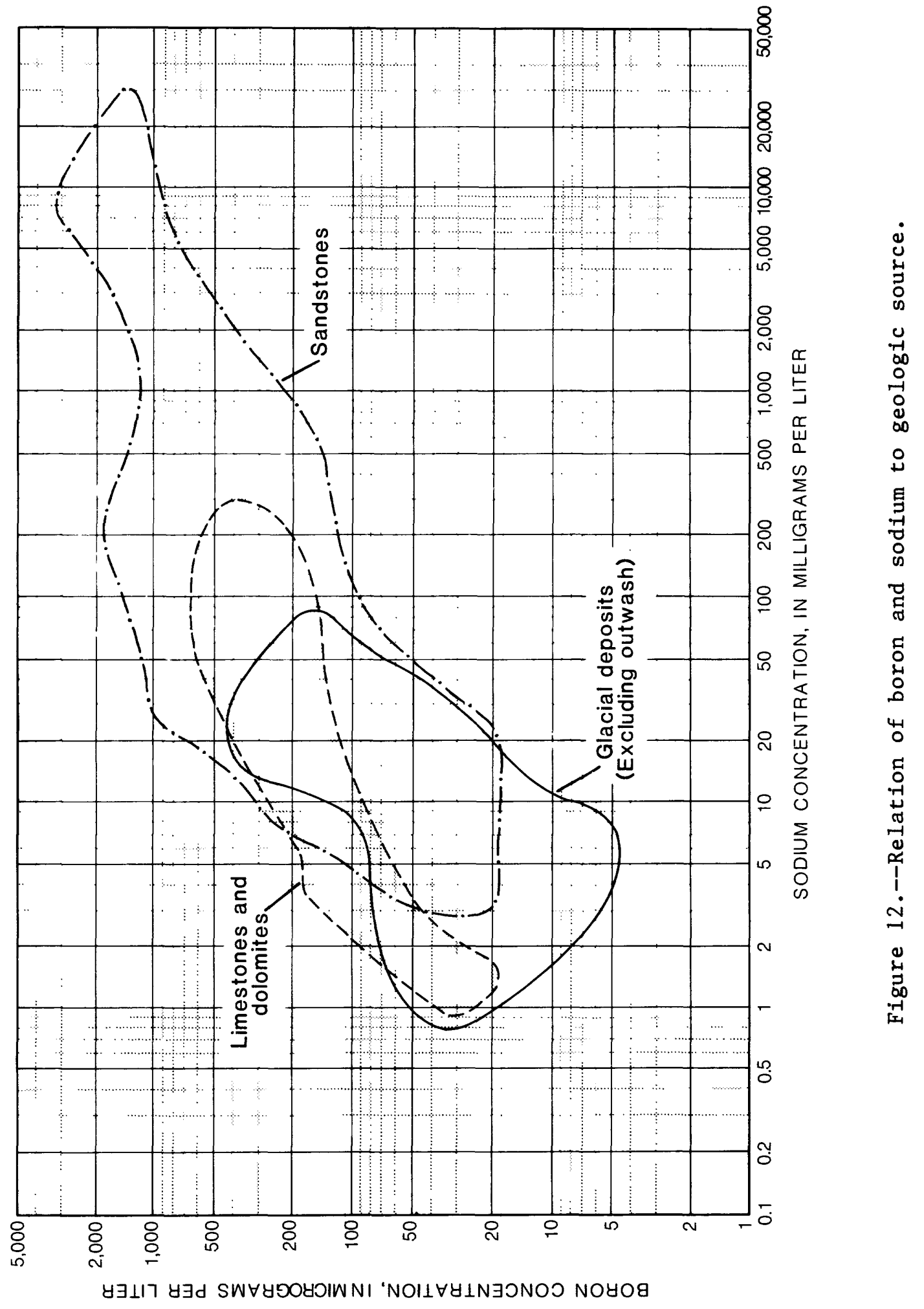




\section{RELATION OF WATER QUALITY TO MINERAL ASSOCIATIONS}

Mineral associations in geologic materials have been studied extensively. Frequently these associations are reflected in the chemical composition of water, and, for this reason, chemical analyses for trace substances serve as a prospecting tool. In the analyses of data for this report, about 40 possible relations between substances were investigated either by simple graphical correlations or by regression analysis. Because data are few and concentration ranges narrow for some substances, correlation was poor, even for some of the better known and understood associations. Extensive treatment is thus unwarranted in this report. significant associations, involving aluminum and its relation to titanium and zirconium, are given as illustrations.

Aluminum is not commonly present in natural waters in concentrations greater than a few tenths of a milligram per liter. Its solubility is sometimes increased owing to the formation of complexes with fluoride and sulfate. Once dissolved, it rapidly hydrolyzes to aluminum hydroxide, which has a low solubility in the $\mathrm{pH}$ range of most natural waters. High concentrations of aluminum occur in water from several geologic sources in Michigan, and a relation between the concentration of aluminum and the composition or texture of deposits is not evident. Shale has been cited as having the highest average aluminum content among sedimentary rocks (Hem, 1972), and a well drilled in the Saginaw Formation, which is primarily sandstone and shale, did yield water having an aluminum concentration of $44,000 \mu \mathrm{g} / \mathrm{L}$. Although the sample was clear when collected, much of the aluminum was probably a finely divided particulate or colloidal form. Water from the same well has a titanium concentration of $3,600 \mu \mathrm{g} / \mathrm{L}$. The author is aware of only one higher concentration of titanium $(5,400 \mu \mathrm{g} / \mathrm{L})$, and that was found in water associated with volcanos in Kamchatka, U.S.S.R. (White and others, 1963).

A plot of titanium concentrations versus aluminum concentrations is shown in figure 13. A regression analysis of the data gave a correlation coefficient of 0.91 . The relation of the two constituents seems consistent with data of Migdisov (1960) who studied the titanium/aluminum ratio of sedimentary rock samples in the U.S.S.R. Migdisov concluded, from an analysis of more than 1,900 samples, that the $\mathrm{TiO}_{2} / \mathrm{Al}_{2} \mathrm{O}$ ratio was 0.053 . Expressed as a Ti/Al ratio, the value is 0.06 . Figure 13 indicates that the Ti/A1 ratio for Michigan ground waters ranges from about 0.1 to about 0.06 . This consistency indicates that the titanium/aluminum association in Michigan ground waters is reliable and might have significance in investigating the occurrence of titanium deposits.

The relation of aluminum to zirconium in water (fig. 14) may al so be of possible significance in geochemical investigations. Zirconium, like aluminum and titanium, seems to occur in concentrations higher than commonly reported. Il'ina and others (1970) found that the zirconium and titanium contents of sandstone, siltstone, and clay are related. This fact, and the apparent relation of aluminum and titanium, suggest that an aluminumzirconium relation can be expected.

Analysis of data for this report, as well as ample geochemical 1 iterature, indicates that identification of other mineral associations may be possible as information accumulates. For example, relations between copper and titanium, manganese and iron, copper and zirconium, vanadium and iron, and boron and sodium are apparent but less definite. Further, 


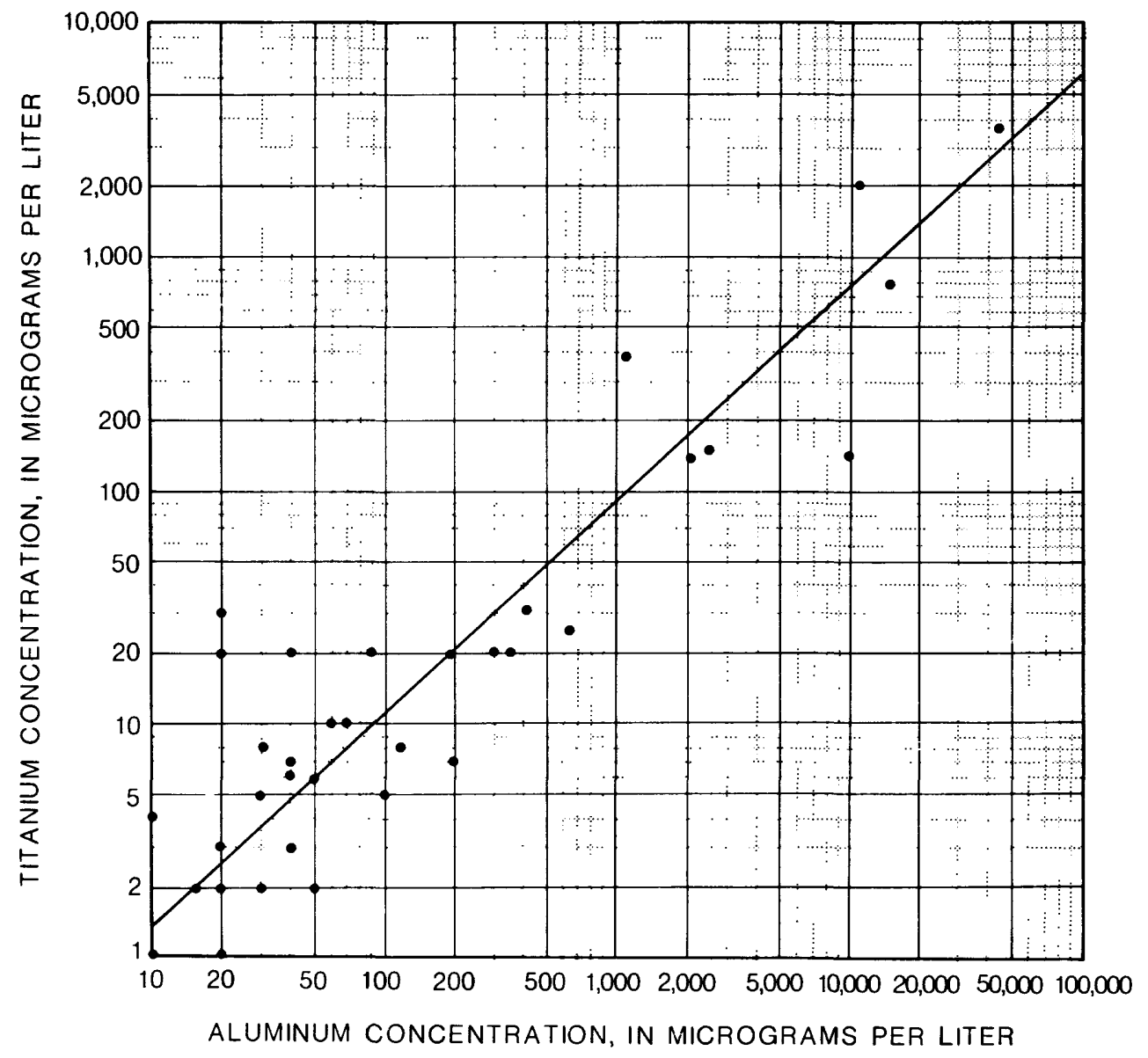

Figure 13.--Relation of titanium to aluminum in water. 


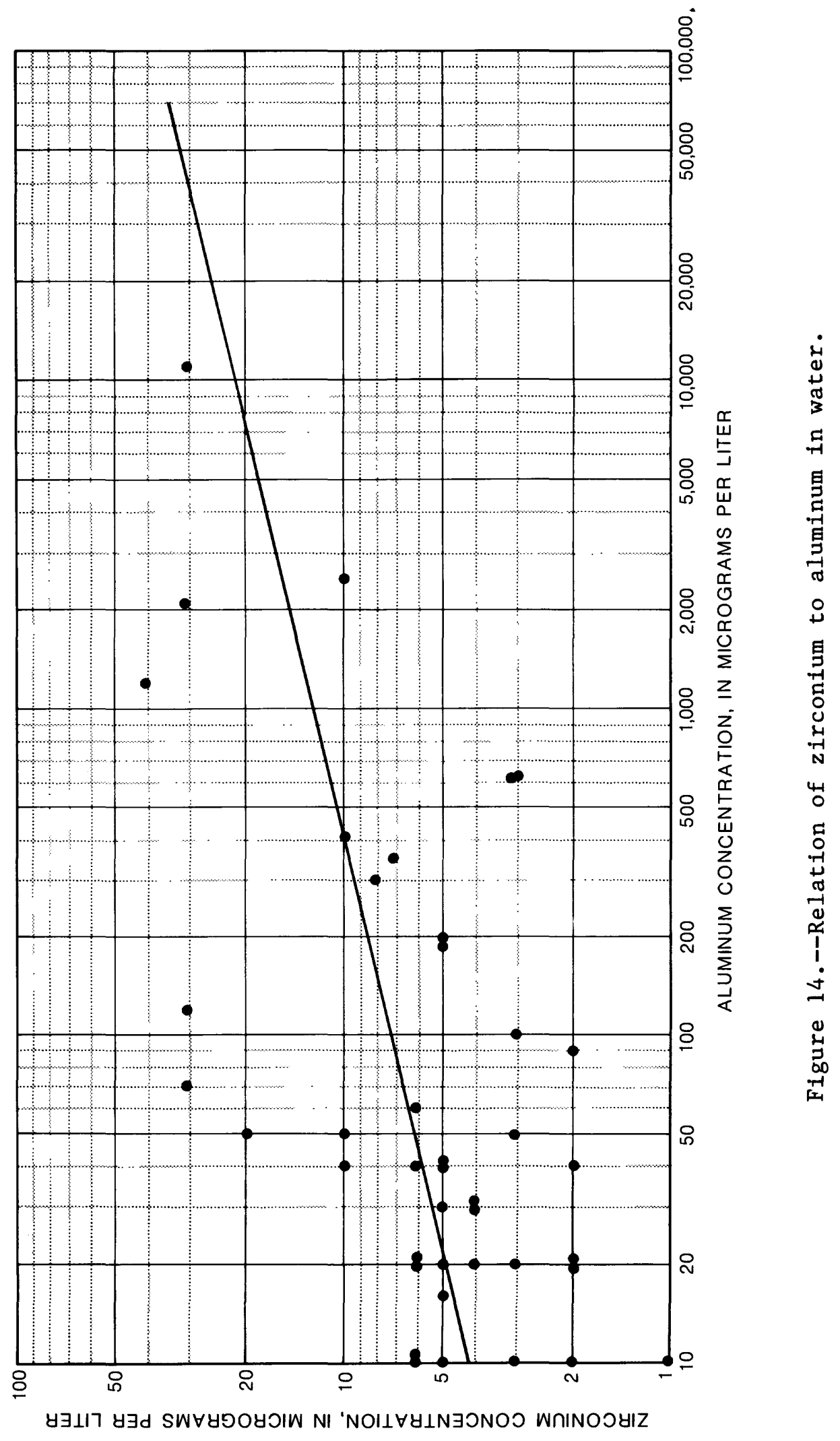


relations between $\mathrm{pH}$ and lead concentrations and between $\mathrm{pH}$ and al uminum are indicated by data. Strontium, which is chemically similar to calcium and generally in close geochemical association with it, increases rapidly as calcium increases. The concentration of strontium in ground water shows a closer relation with magnesium, however. Strontium increases much more rapidly than does magnesium ( $f i g .15)$. Strontium al so increases as sulfate increases.

\section{CONCLUSIONS}

Chemical and physical analyses of 299 samples collected from 1974-87 from 210 wells indicate that the quality characteristics of ground water in Michigan vary widely. Water from bedrock deposits is more highly mineralized than that of glacial deposits. Among glacial deposits, outwash yields the most highly mineralized water. Among bedrock deposits, the Saginaw Formation yields the most highly mineralized water. Calcium and bicarbonate are generally the predominant ions in waters of lower mineralization, whereas sodium, sulfate, and chloride are the predominant ions in waters of higher mineralization. About 78 percent of ground waters may be classified as hard or very hard. Iron concentrations are higher than common in many natural ground waters. Aluminum and titanium occur in unusually high concentrations, and their occurrence seems to be one of mineral association.

Frequency distributions indicate that some waters do not meet U.S. Environmental Protection Agency drinking water regulations for iron, manganese, lead, total dissolved solids, and color. Sulfate, pH, fluoride, copper, chromium, chloride, and cadmium also do not meet regulations at times. Scant data indicate that lead tends to be naturally higher in ground water in the north central part of the Lower Peninsula than in other areas. Dissolved-solids (residue) concentrations, which ranged from 20 to $76,000 \mathrm{mg} / \mathrm{L}$ statewide, are highest in the central part of the Lower Peninsula.

Too few data are available to define conclusive differences in the chemical characteristics of water from each geologic source. Median concentrations, computed for each glacial and bedrock deposit, do provide a basis for comparison.

Mineral associations, notably those of aluminum and titanium and al uminum and zirconium, are evident from the data. Further work will likely develop additional relationships that are tentative at present. 


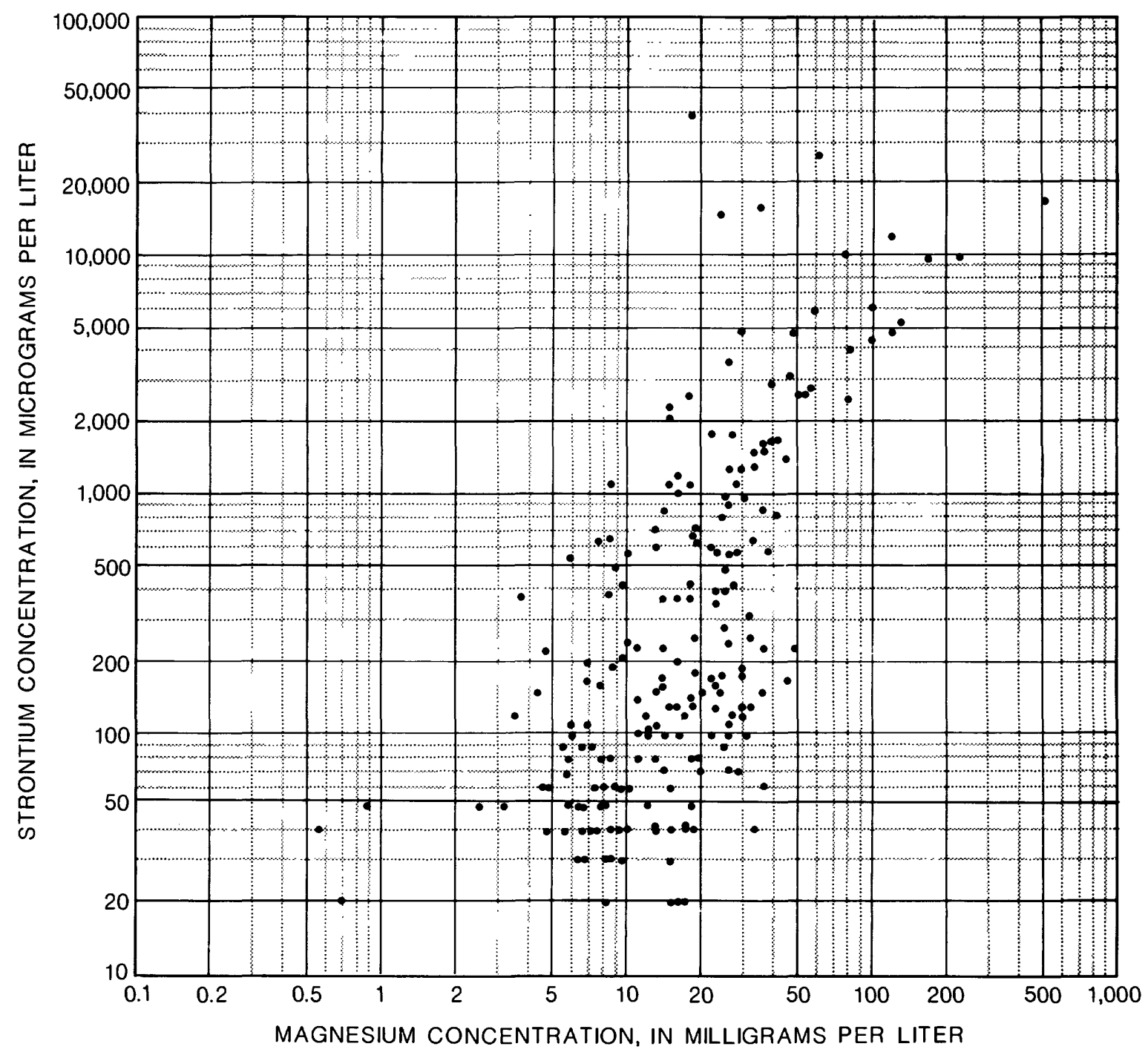

Figure 15.--Relation of strontium to magnesium in water. 


\section{SELECTED REFERENCES}

Barnett, P. R., and Mallory, E. C., 1971, Determination of minor elements in water by emission spectroscopy in Techniques of Water Resources Investigation, Book 5, Chap. A2: U.S. Geological Survey, 31 p.

Cummings, T. R., 1980, Chemical and physical characteristics of natural ground waters in Michigan: A preliminary report: U.S. Geological Survey Open-File Report 80-953, 34 p., 12 figs.

Durfor, C. N., and Becker, Edith, 1964, Public water supplies of the 100 largest cities in the United States, 1962, U.S. Geological Survey Water-Supply Paper 1812, 364 p.

Fishman, M. J., and Friedman, L. C., editors, 1985, Methods for determination of inorganic substances in water and fluvial sediments in Techniques of Water-Resources Investigations, Book 5, Chap. Al: U.S. Geological Survey Open-File Report 85-495, 709 p., 53 figs.

Friedman, L. C., and Erdmann, D. E., 1982, Quality assurance practices for the chemical and biological analyses of water and fluvial sediments in Techniques of Water-Resources Investigations, Book 5, Chap. A6, U.S. Geological Survey, 181 p., 35 figs.

Hem, J. D., 1972, Aluminum: Abundance in common sediments and sedimentary rocks in Wedepohl, K. H., ed., Handbook of Geochemistry: New York, Springer-Verlag, vol. 2, part 1.

Huffman, G. C., 1979a, Ground-water data for Michigan--1977: U.S. Geological Survey Open-File Report 79-332, 75 p., 5 figs., 3 tables.

-- 1979b, Ground-water data for Michigan--1978: U.S. Geological Survey Open-File Report 80-002, 61 p., 5 figs.

---- 1980, Ground-water data for Michigan--1979: U.S. Geological Survey Open-File Report 80-1212, 56 p., 4 figs.

--- 1981, Ground-water data for Michigan--1980: U.S. Geological Survey Open-File Report 81-811, 57 p., 4 figs.

---- 1982, Ground-water data for Michigan--1981: U.S. Geological Survey Open-File Report 82-754, 55 p., 4 figs.

---- 1983, Ground-water data for Michigan--1982: U.S. Geological Survey Open-File Report 83-753, 54 p., 5 figs.

--- 1984, Ground-water data for Michigan--1983: U.S. Geological Survey Open-File Report 84-623, 47 p., 5 figs.

---- 1985, Ground-water data for Michigan--1984: U.S. Geological Survey Open-File Report 85-420, 50 p., 5 figs. 

Open-File Report 86-417W, 50 p., 5 figs.

--- 1988, Ground-water data for Michigan--1986: U.S. Geological Survey Open-File Report 88-87, 52 p., 5 figs.

Huffman, G. C., and Whited, C. R., 1988, Ground-water data for Michigan-1987: U.S. Geological Survey Open-File Report 88-704, 56 p., 4 figs.

Hussey, R. C., 1926, Richman Formation of Michigan: University of Michigan Museum of Geology, contributions, vol. 2, no. 8, p. 113-187.

I1 'ina, N. S., Katchenkov, S. M., and Frukht, D. L., 1970, Distribution of $\mathrm{Ti}$ and $\mathrm{Zr}$ in Predevonian and Devonian sediments of the Moscow syncline: Geochem. Internat., v. 7, 677 p.

Migdisov, A. A., 1960, On the titanium-aluminum ratio in sedimentary rocks: Geochemistry, v. 2, p. 178-194.

Thatcher, L. L., Janzer, V. J., and Edwards, K. W., 1977, methods for the determination of radioactive substances in water and fluvial sediments in Techniques of Water Resources Investigations, Book 5, Chap. A5: U.S. Geological Survey, 95 p.

U.S. Environmental Protection Agency, 1986a, Maximum contaminant levels (subpart B of part 141, National primary drinking-water regulations): U.S. Code of Federal Regulations, Title 40, Parts 100 to 149, revised as of July 1, 1986, p. 524-528, 567-568.

--1986b, Secondary maximum contaminant levels (section 143.3 of part 143, National secondary drinking-water regulations): U.S. Code of Federal Regulations, Title 40, Parts 100 to 149, revised as of July 1, 1986, p. 587-590.

Wershaw, R. L., Fishman, M. J., Grabbe, R. R., and Lowe, L. E., editors, 1983, Methods for the determination of organic substances in water and fluvial Sediments in Techniques of Water-Resources Investigations, Book 5, Chap. A3, U.S. Geological Survey Open-File Report 82-1004, 173 p., 4 figs.

White, D. E., Hem, J.D., and Waring, G. A., 1963, Chemical composition of subsurface waters in Data of Geochemistry: U.S. Geological Survey Prof. Paper 440-F, $67 \mathrm{p}$. 


\section{DEFINITION OF TERMS}

Aquifer. A formation, group of formations, or part of a formation that contains sufficient saturated permeable material to yield significant quantities of water to wells and springs. It is also called a groundwater reservoir.

Bedrock. Designates consolidated rocks underlying glacial deposits.

Concentration. The weight of dissolved solids or sediment per unit volume of water expressed in milligrams per liter (mg/L) or micrograms per 1 iter $(\mu g / L)$.

Ground water. Water that is in the saturated zone from which wells, springs, and ground-water runoff are supplied.

Specific conductance. A measure of the ability of water to conduct an electric current, expressed in microsiemens ( $\mu S$ ) (formerly micromhos) per centimeter at $25^{\circ} \mathrm{C}$. Because the specific conductance is related to amount and type of dissolved material, it is used for approximating the dissolved-solids concentration (in milligrams per liter) to specific conductance (in microsiemens) is in the range 0.5 to 0.8 . 


\section{APPENDIX}

\section{Median values of chemical and physical characteristics of water from geologic sources}

I The number of samples collected from each source and used in computing tabulated modians is as follows: Glacial deposits, undifferentiated, 17; Grave1, 7; Lakebeds, 1; Moraine, 1; Outwash, 18; Sand, 45; Sand and clay, 1; Sand and gravel, 13; Paleozoic dolomite, 1; Pennsylvanian shale, 1; Pennsylvanian sandstone, 1; Saginaw Formation, 27; Michigan Formation, 1; Marsha11 Formation, 7; Antrim Shale, 1; Traverse Group, 3; Dundee Formation, 2; Detroit River Group, 2; Sylvania Sandstone, 1; Bass Islands Dolomite, 1; Engadine Dolomite, 2; Manistique Dolomite, 3; Burnt Bluff Formation, 3; Niagaran Series, 1; Ordovician, Upper, 1; Big Hill Limestone (Hussey, 1926), 1; Trenton Limestone, 2; Trenton-Black River Limestones, 2; Black River Limestone, 2; Mohawkian Series, 1; Hermansville Limestone (of former usage), 1; Prairie du Chien Group, 5; Prairie du Chien Group-Trempealeau Formation, 3; Lake Superior sandstone, 1; Trempealeau-Munising Formations, 5; Munising Formation, 5; Cambrian-Precambrian rocks, 1; Keweenawan supergroup, 1; Jacobsville Sandstone, 8; Freda Sandstone, 2; Copper Harbor Conglomerate, 2; Portage Lake Volcanics, 3; Michigamme Slate, 2; Ironwood Iron-Formation, 1; and Randville Dolomite, 1. Single samples listed as median values. Median values for bismuth and germanium were calculated from reported "less than ()" values, and thus may or may not correspond to true median concentrations. < means less than. -- means no analyses made.]

\begin{tabular}{|c|c|c|c|c|c|c|c|}
\hline Source & $\begin{array}{c}\text { Alka- } \\
\text { inity } \\
\text { (mg/L } \\
\text { as } \\
\left.\mathrm{CaCO}_{3}\right)\end{array}$ & $\begin{array}{l}\text { Alum- } \\
\text { inum, } \\
\text { total } \\
\text { recov- } \\
\text { erable } \\
(\mu g / L \\
\text { as Al) }\end{array}$ & $\begin{array}{c}\text { Arsenic, } \\
\text { total } \\
(\mu g / L \\
\text { as As })\end{array}$ & $\begin{array}{l}\text { Barium, } \\
\text { total } \\
\text { recov- } \\
\text { erable } \\
\text { ( } \mu \text { g/L } \\
\text { as Ba) }\end{array}$ & $\begin{array}{l}\text { Beryl- } \\
\text { lium, } \\
\text { total } \\
\text { recov- } \\
\text { erable } \\
(\mu \mathrm{g} / \mathrm{L} \\
\mathrm{as} \mathrm{Be})\end{array}$ & $\begin{array}{l}\text { Bicar- } \\
\text { bonate, } \\
(\mathrm{mg} / \mathrm{L} \\
\left.\text { as } \mathrm{HCO}_{3}\right)\end{array}$ & $\begin{array}{c}\text { Bismuth } \\
\text { total } \\
(\mu g / L \\
\text { as } B i)\end{array}$ \\
\hline \multicolumn{8}{|l|}{ Glacial deposits } \\
\hline $\begin{array}{l}\text { Glacial deposits, } \\
\text { undifferentiated }\end{array}$ & 290 & 40 & 2 & $<100$ & $<10$ & 200 & $<2$ \\
\hline Gravel & 150 & 40 & 1 & $<100$ & $<10$ & 190 & $<4$ \\
\hline Lakebeds & 110 & 10 & 1 & $<100$ & $<10$ & -- & -- \\
\hline Moraine & 84 & 60 & 4 & $<100$ & $<10$ & 100 & -- \\
\hline Outwash & 148 & 35 & 1 & $<100$ & $<10$ & 160 & \\
\hline Sand & 160 & 30 & 1 & $<100$ & $<10$ & 200 & $<20$ \\
\hline Sand and clay & 144 & 30 & 1 & $<100$ & $<10$ & 170 & $<4$ \\
\hline Sand and gravel & 123 & 30 & 1 & $<100$ & $<10$ & 150 & - \\
\hline \multicolumn{8}{|l|}{ Bedrock deposits } \\
\hline Paleozoic dolomite & 220 & 40 & 1 & $<100$ & $<10$ & 270 & -- \\
\hline Pennsylvanian shale & 107 & 60 & 1 & $<100$ & $<10$ & 130 & -- \\
\hline Pennsylvanian sandstone & 210 & 60 & $<1$ & $<100$ & $<10$ & 260 & -- \\
\hline Saginaw Formation & 230 & 70 & 2 & 100 & $<10$ & 380 & $<15$ \\
\hline Michigan Formation & 170 & 40 & 6 & $<50$ & 0 & 280 & -- \\
\hline Marshall Formation & 168 & 20 & 2 & $<100$ & $<10$ & 225 & -- \\
\hline Antrim Shale & 330 & 8,400 & 1 & 100 & 0 & 400 & -- \\
\hline Traverse Group & 205 & 170 & 1 & $<100$ & $<10$ & 270 & -- \\
\hline Dundee Formation & 196 & 55 & 2 & $<100$ & $<10$ & -- & - \\
\hline Detroit River Group & 246 & 16 & $<1$ & $<100$ & $<10$ & 250 & -- \\
\hline Sylvania Sandstone & 397 & $<10$ & $<1$ & $<100$ & $<10$ & -- & -- \\
\hline Bass Islands Dolomite & 194 & $<10$ & $<1$ & $<100$ & $<10$ & $-\infty$ & - \\
\hline
\end{tabular}


Median values of chemical and physical characteristics of water from geologic sources--Continued

\begin{tabular}{|c|c|c|c|c|c|c|c|}
\hline Source & $\begin{array}{c}\text { Alka- } \\
\text { inity } \\
\text { (mg/L } \\
\text { as } \\
\left.\mathrm{CaCO}_{3}\right)\end{array}$ & $\begin{array}{l}\text { Alum- } \\
\text { inum, } \\
\text { total } \\
\text { recov- } \\
\text { erable } \\
\text { ( } \mu \text { g } / \mathrm{L} \\
\text { as Al) }\end{array}$ & $\begin{array}{c}\text { Arsenic, } \\
\text { total } \\
(\mu g / L \\
\text { as As) }\end{array}$ & $\begin{array}{l}\text { Barium, } \\
\text { total } \\
\text { recov- } \\
\text { erable } \\
\text { ( } \mu g / \mathrm{L} \\
\text { as Ba) }\end{array}$ & $\begin{array}{l}\text { Beryl- } \\
\text { lium, } \\
\text { total } \\
\text { recov- } \\
\text { erable } \\
\text { ( } \mu \mathrm{g} / \mathrm{L} \\
\text { as } \mathrm{Be})\end{array}$ & $\begin{array}{l}\text { Bicar- } \\
\text { bonate, } \\
\text { ( } \mathrm{mg} / \mathrm{L} \\
\left.\text { as } \mathrm{HCO}_{3}\right)\end{array}$ & $\begin{array}{c}\text { Bismuth, } \\
\text { total } \\
\text { ( } \mu g / \mathrm{L} \\
\text { as Bi) }\end{array}$ \\
\hline \multicolumn{8}{|l|}{ Bedrock deposits--continued } \\
\hline Engadine Dolomite & 114 & 195 & 5 & $<100$ & $<10$ & -- & -- \\
\hline Manistique Dolomite & 212 & $<10$ & $<1$ & $<100$ & $<10$ & 320 & -- \\
\hline Burnt Bluff Formation & 156 & 50 & 1 & $<100$ & $<10$ & 275 & $-\infty$ \\
\hline Niagaran Seriesa/ & 171 & $<10$ & $<1$ & $<100$ & $<10$ & -- & -- \\
\hline Ordovician, Upper & 120 & 200 & 0 & 100 & 0 & 170 & -- \\
\hline Big Hill Limestone & 67 & 130 & 1 & $<100$ & $<10$ & 82 & -- \\
\hline Trenton Limestone & 223 & 1,100 & $<1$ & $<100$ & $<10$ & 350 & -- \\
\hline $\begin{array}{l}\text { Trenton-Black River } \\
\text { Limestones }\end{array}$ & 240 & 1,240 & 2 & $<100$ & $<10$ & 370 & -- \\
\hline Black River Limestone & 352 & 21 & 1 & 100 & $<10$ & 430 & -- \\
\hline Mohawkian Series $\underline{b} /$ & 200 & 20 & 1 & 200 & $<10$ & 240 & -- \\
\hline Hermansville Limestone & 198 & $<10$ & $<1$ & $<100$ & $<10$ & -- & -- \\
\hline Prairie du Chien Group & 127 & 20 & $<1$ & $<100$ & $<10$ & 160 & -- \\
\hline $\begin{array}{l}\text { Prairie du Chien Group- } \\
\text { Trempealeau Formation }\end{array}$ & 138 & $<10$ & $<1$ & $<100$ & $<10$ & -- & -- \\
\hline Lake superior sandstone & 164 & 30 & $<1$ & $<100$ & $<10$ & 200 & -- \\
\hline $\begin{array}{l}\text { Trempealeau-Munising } \\
\text { Formations }\end{array}$ & 90 & 30 & 1 & 100 & 0 & 71 & -- \\
\hline Munising Formation & 139 & $<10$ & 1 & $<100$ & $<10$ & 195 & -- \\
\hline $\begin{array}{l}\text { Cambrian-Precambrian } \\
\text { rocks }\end{array}$ & 217 & $<10$ & 2 & $<100$ & $<10$ & -- & -- \\
\hline Keweenawan Supergroup & 125 & $<10$ & $<1$ & $<100$ & $<10$ & -- & -- \\
\hline Jacobsville Sandstone & 120 & 25 & 1 & $<100$ & $<10$ & 170 & -- \\
\hline Freda Sandstone & 120 & 700 & 1 & $<100$ & $<10$ & -- & -- \\
\hline $\begin{array}{l}\text { Copper Harbor } \\
\text { Conglomerate }\end{array}$ & 150 & 40 & $<1$ & $<100$ & $<10$ & -- & -- \\
\hline Portage Lake Volcanics & 90 & 30 & $<1$ & $<100$ & $<10$ & -- & -- \\
\hline Michigamme Slate & 96 & $<10$ & 7 & $<100$ & $<10$ & -- & -- \\
\hline Ironwood Iron-Formation & 185 & $<10$ & $<1$ & $<100$ & $<10$ & -- & -- \\
\hline Randville Dolomite & 157 & $<10$ & $<1$ & $<100$ & $<10$ & -- & -- \\
\hline
\end{tabular}


Median values of chemical and physical characteristics of water from geologic sources--Continued

\begin{tabular}{|c|c|c|c|c|c|c|c|}
\hline & $\begin{array}{l}\text { Boron, } \\
\text { total } \\
\text { recov- } \\
\text { erable } \\
(\mu g / L \\
\text { as } B)\end{array}$ & $\begin{array}{l}\text { Cadmium, } \\
\text { total } \\
\text { recov- } \\
\text { erable } \\
\text { ( } \mu g / \mathrm{L} \\
\text { as Cd) }\end{array}$ & $\begin{array}{l}\text { Calcium } \\
\text { dis } \\
\text { solved } \\
\text { (mg/L } \\
\text { as Ca) }\end{array}$ & $\begin{array}{l}\text { Carbon, } \\
\text { organic } \\
\text { dis- } \\
\text { solved } \\
\text { (mg/L } \\
\text { as C) }\end{array}$ & $\begin{array}{l}\text { Carbon } \\
\text { dioxide, } \\
\text { dis- } \\
\text { solved } \\
\text { (mg/L } \\
\text { as } \mathrm{CO}_{2} \text { ) }\end{array}$ & $\begin{array}{c}\text { Carbonate } \\
(\mathrm{mg} / \mathrm{L} \\
\left.\text { as } \mathrm{Co}_{3}\right)\end{array}$ & $\begin{array}{l}\text { Chlo- } \\
\text { ride, } \\
\text { dis- } \\
\text { solved } \\
\text { (mg/L } \\
\text { as Cl) }\end{array}$ \\
\hline \multicolumn{8}{|l|}{ Glacial deposits } \\
\hline $\begin{array}{l}\text { Glacial deposits, } \\
\text { undifferentiated }\end{array}$ & 10 & $<1$ & 57 & 2.8 & 6.2 & 0 & 4.9 \\
\hline Gravel & 40 & 4 & 42 & 3.7 & 4.7 & 0 & 1.8 \\
\hline Lakebeds & $<20$ & $<1$ & 36 & 3.6 & -- & 0 & 1.6 \\
\hline Moraine & $<20$ & 2 & 25 & 1.7 & 1.6 & 0 & 1.1 \\
\hline Outwash & 30 & $<1$ & 53 & 1.6 & 4.4 & 0 & 4.9 \\
\hline Sand & $<20$ & $<2$ & 44 & 2.0 & 4.9 & 0 & 1.5 \\
\hline Sand and clay & $<20$ & 2 & 42 & .7 & 2.2 & 0 & 1.1 \\
\hline Sand and gravel & 30 & $<1$ & 36 & 2.8 & 3.2 & 0 & 1.5 \\
\hline \multicolumn{8}{|l|}{ Bedrock deposits } \\
\hline Paleozoic dolomite & 80 & $<2$ & 57 & 2.1 & 5.3 & 0 & 1.3 \\
\hline Pennsylvanian shale & 100 & 5 & 65 & 1.2 & 2.6 & 0 & 24 \\
\hline Pennsylvanian sandstone & 610 & 6 & 39 & 7.7 & 5.2 & 0 & 79 \\
\hline Saginaw Formation & 390 & $<1$ & 130 & 2.0 & 28 & 0 & 180 \\
\hline Michigan Formation & 360 & 0 & 110 & 1.5 & 44 & 0 & 440 \\
\hline Marshall Formation & 80 & $<1$ & 54 & 1.6 & 9.0 & 0 & 15 \\
\hline Antrim Shale & 520 & 1 & 21 & .8 & 16 & 0 & 53 \\
\hline Traverse Group & $<20$ & $<2$ & 93 & 1.0 & 11 & 0 & 25 \\
\hline Dundee Formation & 270 & $<1$ & 57 & 7.0 & -- & -- & 10 \\
\hline Detroit River Group & 105 & $<1$ & 82 & -- & 6.3 & 0 & .7 \\
\hline Sylvania Sandstone & 110 & $<1$ & 200 & 2.3 & - & $-\infty$ & 47 \\
\hline Bass Islands Dolomite & 130 & $<1$ & 400 & 3.5 & - & - & 9.4 \\
\hline Engadine Dolomite & 80 & 1 & 130 & 4.1 & - & -- & 1.2 \\
\hline Manistique Dolomite & $<10$ & $<1$ & 58 & 3.5 & 25 & 0 & 2.3 \\
\hline Burnt Bluff Formation & 20 & $<1$ & 79 & 2.5 & 24 & 0 & 6.7 \\
\hline Niagaran Series & 130 & $<1$ & 73 & 1.1 & -- & -- & 3.9 \\
\hline Ordovician, Upper & 450 & 0 & 92 & 5.7 & 4.3 & 0 & 280 \\
\hline Big Hill Limestone & 560 & 2 & 230 & .6 & 2.1 & 0 & 270 \\
\hline Trenton Limestone & 135 & $<1$ & 54 & 4.8 & 17 & 0 & 5.4 \\
\hline $\begin{array}{l}\text { Trenton-Black River } \\
\text { Limestones }\end{array}$ & $<20$ & n 3 & 86 & 2.3 & 23 & 0 & 17 \\
\hline Black River Limestone & 260 & $<1$ & 84 & 1.6 & 86 & 0 & 41 \\
\hline Mohawkian Series & 80 & 2 & 43 & .8 & 6.0 & 0 & 1.0 \\
\hline Hermansville Limestone & $<10$ & $<1$ & 52 & 6.0 & -- & -- & .6 \\
\hline Prairie du Chien Group & 145 & $<1$ & 34 & 1.8 & 4.6 & 0 & 0.8 \\
\hline
\end{tabular}


Median values of chemical and physical characteristics of water from geologic sources--Continued

\begin{tabular}{|c|c|c|c|c|c|c|c|}
\hline & $\begin{array}{l}\text { Boron, } \\
\text { total } \\
\text { recov- } \\
\text { erable } \\
(\mu g / L \\
\text { as B) }\end{array}$ & $\begin{array}{l}\text { Cadmium, } \\
\text { total } \\
\text { recov- } \\
\text { erable } \\
\text { ( } \mu \text { g/L } \\
\text { as Cd) }\end{array}$ & $\begin{array}{l}\text { Calcium } \\
\text { dis- } \\
\text { solved } \\
\text { (mg/L } \\
\text { as Ca) }\end{array}$ & $\begin{array}{l}\text { Carbon, } \\
\text { organic } \\
\text { dis- } \\
\text { solved } \\
\text { (mg/L } \\
\text { as C) }\end{array}$ & $\begin{array}{c}\text { Carbon } \\
\text { dioxide, } \\
\text { dis- } \\
\text { solved } \\
\text { (mg/L } \\
\text { as } \mathrm{CO}_{2} \text { ) }\end{array}$ & $\begin{array}{c}\text { Carbonate } \\
\text { (mg/L } \\
\left.\text { as } \mathrm{CO}_{3}\right)\end{array}$ & $\begin{array}{l}\text { Chlo- } \\
\text { ride, } \\
\text { dis- } \\
\text { solved } \\
\text { (mg/L } \\
\text { as } C l \text { ) }\end{array}$ \\
\hline \multicolumn{8}{|l|}{ Bedrock deposits--continued } \\
\hline $\begin{array}{l}\text { Prairie du Chien Group- } \\
\text { Trempealeau Formation }\end{array}$ & 220 & $<1$ & 72 & .7 & -- & -- & 28 \\
\hline Lake Superior sandstone & 110 & $<20$ & 68 & 1.6 & 5.0 & 0 & 160 \\
\hline $\begin{array}{l}\text { Trempealeau-Munising } \\
\text { Formations }\end{array}$ & 30 & 0 & 27 & 2.9 & 4.5 & 0 & 4.0 \\
\hline Munising Formation & 20 & $<1$ & 39 & 1.1 & 7.2 & 0 & 2.7 \\
\hline $\begin{array}{l}\text { Cambrian-Precambrian } \\
\text { rocks }\end{array}$ & 20 & $<1$ & 44 & 1.5 & -- & -- & 1.3 \\
\hline Keweenawan Supergroup & 140 & $<1$ & 25 & 3.7 & -- & -- & 8.9 \\
\hline Jacobsville Sandstone & 75 & $<1$ & 30 & 2.7 & 9.6 & 0 & 2.8 \\
\hline Freda Sandstone & 640 & $<1$ & 28 & 2.2 & -- & -- & 11 \\
\hline $\begin{array}{l}\text { Copper Harbor } \\
\text { Conglomerate }\end{array}$ & 510 & $<1$ & 42 & 2.6 & -- & -- & 5.4 \\
\hline Portage Lake Volcanics & 700 & $<1$ & 10 & 1.6 & -- & -- & 5.3 \\
\hline Michigamme slate & 11 & $<1$ & 32 & 1.4 & -- & -- & 8.9 \\
\hline Ironwood Iron-Formation & 80 & $<1$ & 41 & 1.1 & -- & -- & 8.2 \\
\hline Randville Dolomite & 30 & $<1$ & 38 & 2.7 & -- & -- & .8 \\
\hline
\end{tabular}


Median values of chemical and physical characteristics of water from geologic sources--Continued

\begin{tabular}{|c|c|c|c|c|c|c|c|}
\hline & $\begin{array}{l}\text { Chro- } \\
\text { mium, } \\
\text { total } \\
\text { recov- } \\
\text { erable } \\
\text { ( } \mu \mathrm{g} / \mathrm{L} \\
\text { as } \mathrm{Cr})\end{array}$ & $\begin{array}{l}\text { Cobalt, } \\
\text { total } \\
\text { recov- } \\
\text { erable } \\
(\mu \mathrm{g} / \mathrm{L} \\
\text { as Co })\end{array}$ & $\begin{array}{l}\text { Color } \\
\text { (plat- } \\
\text { inum- } \\
\text { cobalt } \\
\text { units) }\end{array}$ & $\begin{array}{c}\text { Copper, } \\
\text { total } \\
\text { recov- } \\
\text { erable } \\
(\mu \mathrm{g} / \mathrm{L} \\
\text { as Cu) }\end{array}$ & $\begin{array}{l}\text { Cyanide, } \\
\text { total } \\
\text { (mg/L } \\
\text { as CN) }\end{array}$ & $\begin{array}{l}\text { Depth } \\
\text { of well } \\
\text { (feet) }\end{array}$ & $\begin{array}{l}\text { Fluo- } \\
\text { ride, } \\
\text { dis- } \\
\text { solved } \\
\text { (mg/L } \\
\text { as F) }\end{array}$ \\
\hline \multicolumn{8}{|l|}{ Glacial deposits } \\
\hline $\begin{array}{l}\text { Glacial deposits, } \\
\text { undifferentiated }\end{array}$ & $<20$ & $<1$ & 1 & 5 & 0.00 & 72 & 0.10 \\
\hline Gravel & $<20$ & $<3$ & 3 & 6 & .00 & 65 & .10 \\
\hline Lakebeds & 10 & $<1$ & 15 & 4 & $<.01$ & 21 & $<.10$ \\
\hline Moraine & $<20$ & 3 & 1 & 15 & .00 & 103 & .10 \\
\hline Outwash & $<20$ & $<2$ & 3 & 4 & .00 & 56 & .15 \\
\hline Sand & $<20$ & $<2$ & 5 & 4 & .00 & 87 & .10 \\
\hline Sand and clay & $<20$ & 2 & 5 & 5 & .00 & 54 & .10 \\
\hline Sand and gravel & $<20$ & $<2$ & 10 & 7 & .00 & 60 & .10 \\
\hline \multicolumn{8}{|l|}{ Bedrock deposits } \\
\hline Paleozoic dolomite & $<20$ & 2 & 10 & 7 & .00 & 67 & $<.10$ \\
\hline Pennsylvanian shale & $<20$ & 2 & 10 & $<2$ & .00 & 172 & .50 \\
\hline Pennsyluanian sandstone & $<20$ & $<2$ & 5 & $<2$ & .00 & 270 & .30 \\
\hline Saginaw Formation & 10 & 2 & 2 & 16 & $<.01$ & 207 & .30 \\
\hline Michigan Formation & 10 & 0 & 4 & 3 & .01 & 245 & .80 \\
\hline Marshall Formation & $<20$ & $<1$ & 4 & 6 & $<.01$ & 180 & .40 \\
\hline Antrim Shale & 20 & 8 & 3 & 29 & .00 & 90 & .90 \\
\hline Traverse Group & $<20$ & 3 & 10 & 5 & .00 & 91 & 1.4 \\
\hline Dundee Formation & $<10$ & $<1$ & 72 & 4 & $<.01$ & 122 & .60 \\
\hline Detroit River Group & 11 & $<1$ & 4 & 4 & $<.01$ & 64 & 1.0 \\
\hline Sylvania Sandstone & $<10$ & $<1$ & 5 & 7 & $<.01$ & 97 & .70 \\
\hline Bass Islands Dolomite & 10 & $<1$ & 5 & 2 & $<.01$ & 112 & 1.4 \\
\hline Engadine Dolomite & $<10$ & 2 & 32 & 30 & $<.01$ & 96 & .80 \\
\hline Manistique Dolomite & 10 & $<1$ & 3 & 5 & $<.01$ & 102 & .40 \\
\hline Burnt Bluff Formation & $<20$ & 1 & 3 & 6 & $<.01$ & 185 & .80 \\
\hline Niagaran Series & $<10$ & $<1$ & 3 & 2 & $<.01$ & 560 & 2.0 \\
\hline Ordovician, Upper & 20 & 0 & 0 & 2 & .01 & 120 & 1.8 \\
\hline Big Hill Limestone & $<20$ & 2 & 5 & 5 & .00 & 225 & $<.10$ \\
\hline Trenton Limestone & 20 & 1 & 4 & 22 & .00 & 84 & .20 \\
\hline $\begin{array}{l}\text { Trenton-Black River } \\
\text { Limestones }\end{array}$ & $<20$ & 1 & 5 & 4 & $<.01$ & 222 & .10 \\
\hline Black River Limestone & 6 & 2 & 4 & 4 & $<.01$ & 245 & .30 \\
\hline Mohawkian Series & 30 & 2 & 15 & 2 & .00 & 65 & .20 \\
\hline Hermansville Limestone & 30 & $<1$ & 13 & 19 & $<.01$ & 38 & .10 \\
\hline Prairie du Chien Group & $<20$ & $<1$ & 5 & 4 & $<0.01$ & 280 & 0.40 \\
\hline
\end{tabular}


Median values of chemical and physical characteristics of water from geologic sources--Continued

\begin{tabular}{|c|c|c|c|c|c|c|c|}
\hline & $\begin{array}{l}\text { Chro- } \\
\text { mium, } \\
\text { totai } \\
\text { recov- } \\
\text { erable } \\
\text { ( } \mu g / L \\
\text { as Cr) }\end{array}$ & $\begin{array}{l}\text { Cobalt, } \\
\text { total } \\
\text { recov- } \\
\text { erable } \\
\text { ( } \mu g / L \\
\text { as Co) }\end{array}$ & $\begin{array}{l}\text { Color } \\
\text { (plat- } \\
\text { inum- } \\
\text { cobalt } \\
\text { units) }\end{array}$ & $\begin{array}{c}\text { Copper, } \\
\text { total } \\
\text { recov- } \\
\text { erable } \\
(\mu g / L \\
\text { as } \mathrm{Cu})\end{array}$ & $\begin{array}{l}\text { Cyanide, } \\
\text { total } \\
\text { (mg/L } \\
\text { as CN) }\end{array}$ & $\begin{array}{l}\text { Depth } \\
\text { of well } \\
\text { (feet) }\end{array}$ & $\begin{array}{l}\text { Fluo- } \\
\text { ride, } \\
\text { dis- } \\
\text { solved } \\
\text { (mg/L } \\
\text { as F) }\end{array}$ \\
\hline \multicolumn{8}{|l|}{ Bedrock deposits--continued } \\
\hline $\begin{array}{l}\text { Prairie du Chien Group- } \\
\text { Trempealeau Formation }\end{array}$ & 10 & 1 & 3 & 9 & $<.01$ & 665 & .50 \\
\hline Lake Superior sandstone & $<20$ & $<1$ & 5 & 4 & .00 & 1,160 & .40 \\
\hline $\begin{array}{l}\text { Trempealeau-Munising } \\
\text { Formations }\end{array}$ & 20 & 0 & 3 & 4 & .00 & 300 & .10 \\
\hline Munising Formation & $<10$ & 4 & 2 & 8 & $<.01$ & 200 & .10 \\
\hline $\begin{array}{l}\text { Cambrian-Precambrian } \\
\text { rocks }\end{array}$ & $<10$ & $<1$ & 5 & 140 & $<.01$ & 122 & .10 \\
\hline Keweenawan Supergroup & 30 & 1 & 2 & 8 & $<.01$ & 230 & .10 \\
\hline Jacobsville Sandstone & $<20$ & 1 & 3 & 8 & .00 & 185 & .10 \\
\hline Freda Sandstone & 11 & 1 & 3 & 48 & $<.01$ & 88 & .40 \\
\hline $\begin{array}{l}\text { Copper Harbor } \\
\text { Conglomerate }\end{array}$ & 16 & $<1$ & 5 & 8 & $<.01$ & 230 & .11 \\
\hline Portage Lake Volcanics & 10 & 1 & 5 & 10 & $<.01$ & 100 & .60 \\
\hline Michigamme slate & 16 & 2 & 6 & 3 & $<.01$ & 276 & .26 \\
\hline Ironwood Iron-Formation & $<10$ & $<1$ & 5 & 2 & $<.01$ & 390 & .10 \\
\hline Randville Dolomite & 10 & 2 & 1 & 11 & $<.01$ & 100 & .20 \\
\hline
\end{tabular}


Median values of chemical and physical characteristics of water from geologic sources--Continued

\begin{tabular}{|c|c|c|c|c|c|c|c|}
\hline & $\begin{array}{l}\text { Gallium, } \\
\text { total } \\
(\mu g / L \\
\text { as Ga) }\end{array}$ & $\begin{array}{l}\text { Germa- } \\
\text { nium, } \\
\text { total } \\
(\mu \mathrm{g} / \mathrm{L} \\
\text { as } \mathrm{Ge})\end{array}$ & $\begin{array}{c}\text { Hardness, } \\
\text { total } \\
(\mathrm{mg} / \mathrm{L} \\
\text { as } \\
\left.\mathrm{CaCO}_{3}\right)\end{array}$ & $\begin{array}{c}\text { Hardness, } \\
\text { noncar- } \\
\text { bonate, } \\
\text { total } \\
(\mathrm{mg} / \mathrm{L} \\
\text { as } \\
\left.\mathrm{CaCO}_{3}\right)\end{array}$ & $\begin{array}{l}\text { Iron, } \\
\text { dis- } \\
\text { solved } \\
(\mu g / L \\
\text { as Fe) }\end{array}$ & $\begin{array}{l}\text { Iron, } \\
\text { total } \\
\text { recov- } \\
\text { erable } \\
\text { ( } \mu \text { g/L } \\
\text { as Fe) }\end{array}$ & $\begin{array}{l}\text { Lead, } \\
\text { total } \\
\text { recov- } \\
\text { erable } \\
(\mu g / L \\
\text { as Pb) }\end{array}$ \\
\hline \multicolumn{8}{|l|}{ Glacial deposits } \\
\hline $\begin{array}{l}\text { Glacial deposits, } \\
\text { undifferentiated }\end{array}$ & $<1$ & $<4$ & 210 & 27 & 270 & 470 & 4 \\
\hline Gravel & $<1$ & $<4$ & 160 & 15 & 57 & 350 & 2 \\
\hline Lakebeds & -- & -- & 120 & 10 & 10 & 380 & $<1$ \\
\hline Moraine & -- & -- & 85 & 2 & 40 & 160 & $<2$ \\
\hline outwash & $<6$ & $<20$ & 185 & 16 & 530 & 1,380 & 5 \\
\hline Sand & $<1$ & $<6$ & 170 & 8 & 50 & 270 & 7 \\
\hline Sand and clay & -- & -- & 140 & 0 & 40 & 580 & 6 \\
\hline Sand and gravel & -- & -- & 130 & 7 & 1,200 & 2,000 & 10 \\
\hline \multicolumn{8}{|l|}{ Bedrock deposits } \\
\hline Paleozoic dolomite & -- & -- & 250 & 30 & 160 & 300 & 12 \\
\hline Pennsyluanian shale & -- & -- & 230 & 120 & 250 & 320 & 160 \\
\hline Pennsylvanian sandstone & -- & -- & 150 & 0 & 550 & 890 & 150 \\
\hline Saginaw Formation & $<20$ & $<20$ & 460 & 210 & 570 & 1,500 & 8 \\
\hline Michigan Formation & -- & -- & 390 & 220 & 710 & 780 & 2 \\
\hline Marshall Formation & - & - & 250 & 76 & 270 & 840 & 5 \\
\hline Antrim shale & - & -- & 91 & 0 & 20 & 7,200 & 10 \\
\hline Träverse Group & -- & - & 310 & 69 & 120 & 610 & 5 \\
\hline Dundee Formation & - & -- & 290 & 92 & 1,990 & 1,980 & 2 \\
\hline Detroit River Group & -- & -- & 360 & 140 & 50 & 85 & 2 \\
\hline Sylvania Sandstone & -- & -- & 600 & 200 & 1,800 & 2,300 & $<5$ \\
\hline Bass Islands Dolomite & -- & -- & 1,500 & 1,300 & 40 & 50 & $<5$ \\
\hline Engadine Dolomite & -- & -- & 515 & 400 & 1,290 & 3,200 & 6 \\
\hline Manistique Dolomite & -- & -- & 230 & 9 & 8 & 90 & 7 \\
\hline Burnt Bluff Formation & - & -- & 350 & 26 & 210 & 710 & 1 \\
\hline Niagaran Series & -- & -- & 330 & 160 & 260 & 610 & $<5$ \\
\hline Ordovician, Upper & -- & -- & 350 & 230 & 60 & 120 & 0 \\
\hline Big Hill Limestone & -- & -- & 900 & 840 & 50 & 600 & 15 \\
\hline Trenton Limestore & -- & -- & 240 & 16 & 158 & 1,820 & $<5$ \\
\hline $\begin{array}{l}\text { Trenton-Black River } \\
\text { Limestones }\end{array}$ & -- & -- & 330 & 89 & 660 & 1,040 & 16 \\
\hline Black River Limestone & $\cdots$ & -- & 330 & 48 & 39 & 165 & 2 \\
\hline Mohawkian Series & -- & -- & 190 & 0 & 240 & 230 & 10 \\
\hline Hermansville Limestone & -- & -- & 240 & 43 & 520 & 550 & $<5$ \\
\hline Prairie du Chien Group & -- & -- & 150 & 6 & 49 & 250 & 6 \\
\hline
\end{tabular}


Median values of chemical and physical characteristics of water from geologic sources--Continued

\begin{tabular}{|c|c|c|c|c|c|c|c|}
\hline & $\begin{array}{l}\text { Gallium, } \\
\text { total } \\
(\mu g / L \\
\text { as Ga) }\end{array}$ & $\begin{array}{l}\text { Germa- } \\
\text { nium, } \\
\text { total } \\
(\mu g / L \\
\text { as } \mathrm{Ge})\end{array}$ & $\begin{array}{c}\text { Hardness, } \\
\text { total } \\
(\mathrm{mg} / \mathrm{L} \\
\mathrm{as} \\
\left.\mathrm{CaCO}_{3}\right)\end{array}$ & $\begin{array}{c}\text { Hardness, } \\
\text { noncar- } \\
\text { bonate, } \\
\text { total } \\
\text { (mg/L } \\
\text { as } \\
\left.\mathrm{CaCO}_{3}\right)\end{array}$ & $\begin{array}{l}\text { Iron, } \\
\text { dis- } \\
\text { solved } \\
\text { ( } \mu \mathrm{g} / \mathrm{L} \\
\text { as } \mathrm{Fe})\end{array}$ & $\begin{array}{l}\text { Iron, } \\
\text { total } \\
\text { recov- } \\
\text { erable } \\
\text { ( } \mu g / L \\
\text { as Fe) }\end{array}$ & $\begin{array}{l}\text { Lead, } \\
\text { total } \\
\text { recov- } \\
\text { erable } \\
(\mu g / L \\
\text { as } \mathrm{Pb})\end{array}$ \\
\hline \multicolumn{8}{|l|}{ Bedrock deposits--continued } \\
\hline $\begin{array}{l}\text { Prairie du Chien Group- } \\
\text { Trempealeau Formation }\end{array}$ & -- & -- & 320 & 82 & 12 & 810 & 6 \\
\hline Lake Superior sandstone & -- & -- & 290 & 130 & 90 & 70 & 41 \\
\hline $\begin{array}{l}\text { Trempealeau-Munising } \\
\text { Formations }\end{array}$ & -- & -- & 100 & 11 & 40 & 240 & $<5$ \\
\hline Munising Formation & -- & -- & 170 & 13 & 27 & 180 & $<5$ \\
\hline $\begin{array}{l}\text { Cambrian-Precambrian } \\
\text { rocks }\end{array}$ & -- & -- & 230 & 17 & 20 & 1,800 & 11 \\
\hline Keweenawan Supergroup & -- & - & 87 & 0 & 7 & $<10$ & $<5$ \\
\hline Jacobsville Sandstone & -- & -- & 114 & 0 & 15 & 130 & 6 \\
\hline Freda Sandstone & -- & -- & 101 & 2 & 16 & 1,150 & $<5$ \\
\hline $\begin{array}{l}\text { Copper Harbor } \\
\text { Conglomerate }\end{array}$ & -- & -- & 127 & $<1$ & 16 & 170 & 14 \\
\hline Portage Lake Volcanics & -- & -- & 29 & 0 & 47 & 120 & $<5$ \\
\hline Michigamne slate & -- & -- & 130 & 30 & 164 & 540 & $<5$ \\
\hline Ironwood Iron-Formation & -- & -- & 180 & 1 & 23 & 40 & $<5$ \\
\hline Randville Dolomite & -- & -- & 170 & 12 & 5 & 7,100 & $<5$ \\
\hline
\end{tabular}


Median values of chemical and physical characteristics of water from geologic sources--Continued

\begin{tabular}{|c|c|c|c|c|c|c|c|}
\hline & $\begin{array}{l}\text { Lithium, } \\
\text { total } \\
\text { recov- } \\
\text { erable } \\
\text { ( } \mu \mathrm{g} / \mathrm{L} \\
\text { as Li) }\end{array}$ & $\begin{array}{l}\text { Magne- } \\
\text { sium, } \\
\text { dis- } \\
\text { solved } \\
\text { (mg/L } \\
\text { as Mg) }\end{array}$ & $\begin{array}{l}\text { Manga- } \\
\text { nese, } \\
\text { dis- } \\
\text { solved } \\
\mu g / L \\
\text { as } M n)\end{array}$ & $\begin{array}{l}\text { Manga- } \\
\text { nese, } \\
\text { total } \\
\text { recov- } \\
\text { erable } \\
(\mu g / L \\
\text { as } M n)\end{array}$ & $\begin{array}{l}\text { Mercury, } \\
\text { total } \\
\text { recov- } \\
\text { erable } \\
\text { ( } \mu \mathrm{g} / \mathrm{L} \\
\text { as } \mathrm{Hg})\end{array}$ & $\begin{array}{l}\text { Molyb- } \\
\text { denum, } \\
\text { total } \\
\text { recov- } \\
\text { erable } \\
\text { ( } \mu g / L \\
\text { as Mo }\end{array}$ & $\begin{array}{l}\text { Nickel } \\
\text { total } \\
\text { recov- } \\
\text { erable } \\
(\mu g / L \\
\text { as Ni) }\end{array}$ \\
\hline \multicolumn{8}{|l|}{ Glacial deposits } \\
\hline $\begin{array}{l}\text { Glacial deposits, } \\
\text { undifferentiated }\end{array}$ & $<10$ & 17 & 37 & 40 & $<0.50$ & 3 & 3 \\
\hline Gravel & $<10$ & 8.5 & 40 & 40 & $<.50$ & 1 & 2 \\
\hline Lakebeds & $<10$ & 7.2 & 13 & 40 & $<.10$ & $<1$ & 3 \\
\hline Moraine & $<10$ & 5.6 & $<10$ & $<10$ & $<.50$ & 2 & 10 \\
\hline Outwash & $<10$ & 18 & 20 & 25 & $<.10$ & 4 & 2 \\
\hline Sand & $<10$ & 13 & 10 & 20 & $<.50$ & 1 & 3 \\
\hline Sand and clay & $<10$ & 8.0 & $<10$ & 20 & $<.50$ & 1 & 21 \\
\hline Sand and gravel & $<10$ & 9.4 & 43 & 50 & $<.50$ & 1 & 5 \\
\hline \multicolumn{8}{|l|}{ Bedrock deposits } \\
\hline Paleozoic dolomite & 20 & 26 & $<10$ & $<10$ & $<.50$ & 6 & 8 \\
\hline Pennsylvanian shale & 60 & 16 & 50 & 50 & $<.50$ & $<1$ & 3 \\
\hline PEnnsylvanian sandstone & 40 & 23 & 20 & 20 & $<.50$ & 3 & 3 \\
\hline Saginaw Formation & 30 & 39 & 60 & 110 & $<.50$ & 2 & 2 \\
\hline Michigan Formation & 30 & 27 & 10 & 30 & $<.10$ & 5 & 1 \\
\hline Marshall Formation & $<10$ & 22 & 60 & 70 & $<.50$ & 1 & 3 \\
\hline Antrim Shale & 80 & 9.3 & 20 & 150 & .10 & 6 & 15 \\
\hline Traverse Group & $<10$ & 18 & 12 & 20 & $<.50$ & $<1$ & 3 \\
\hline Dundee Formation & 25 & 36 & 36 & 55 & .21 & 2 & 2 \\
\hline Detroit River Group & 31 & 38 & 12 & 20 & $<.30$ & 2 & 2 \\
\hline Sylvania Sandstone & 20 & 24 & 26 & 30 & $<.10$ & 2 & 1 \\
\hline Bass Islands Dolomite & 50 & 120 & 10 & 20 & $<.10$ & $<1$ & 2 \\
\hline Engadine Dolomite & 26 & 46 & 86 & 110 & .06 & 5 & 2 \\
\hline Manistique Dolomite & $<10$ & 18 & 2 & $<10$ & $<.10$ & $<1$ & $<1$ \\
\hline Burnt Bluff Formation & 40 & 30 & 7 & 10 & .10 & 1 & 2 \\
\hline Niagaran Series & 20 & 35 & 8 & 10 & $<.10$ & 3 & 2 \\
\hline Ordovician, Upper & 70 & 30 & 70 & 50 & .30 & 2 & 0 \\
\hline Big Hill Limestone & 50 & 80 & 50 & 50 & $<.50$ & 4 & 11 \\
\hline Trenton Limestone & 10 & 25 & 14 & 50 & .15 & $<.1$ & 2 \\
\hline $\begin{array}{l}\text { Trenton-Black River } \\
\text { Limestones }\end{array}$ & $<10$ & 28 & 16 & 30 & .15 & 2 & 7 \\
\hline Black River Limestone & 15 & 30 & 16 & 25 & .21 & 2 & 4 \\
\hline Mohawkian Series & $<10$ & 19 & 20 & $<10$ & $<.50$ & 1 & 8 \\
\hline Hermansville Limestone & $<10$ & 27 & 16 & 20 & $<.10$ & 1 & $<1$ \\
\hline Prairie du Chien Group & $<10$ & 15 & 7 & $<10$ & .10 & 1 & 4 \\
\hline
\end{tabular}


Median values of chemical and physical characteristics of water from geologic sources--Continued

\begin{tabular}{|c|c|c|c|c|c|c|c|}
\hline & $\begin{array}{l}\text { Lithium, } \\
\text { total } \\
\text { recov- } \\
\text { erable } \\
\text { ( } \mu \mathrm{g} / \mathrm{L} \\
\text { as Li) }\end{array}$ & $\begin{array}{l}\text { Magne- } \\
\text { sium, } \\
\text { dis- } \\
\text { solved } \\
\text { (mg/L } \\
\text { as Mg) }\end{array}$ & $\begin{array}{l}\text { Manga- } \\
\text { nese, } \\
\text { dis- } \\
\text { solved } \\
\mu g / L \\
\text { as Mn) }\end{array}$ & $\begin{array}{l}\text { Manga- } \\
\text { nese, } \\
\text { total } \\
\text { recov- } \\
\text { erable } \\
(\mu g / L \\
\text { as } M n)\end{array}$ & $\begin{array}{l}\text { Mercury, } \\
\text { total } \\
\text { recov- } \\
\text { erable } \\
\text { ( } \mu \mathrm{g} / \mathrm{L} \\
\text { as } \mathrm{Hg})\end{array}$ & $\begin{array}{l}\text { Molyb- } \\
\text { denum, } \\
\text { total } \\
\text { recov- } \\
\text { erable } \\
\text { ( } \mu \text { g /L } \\
\text { as Mo }\end{array}$ & $\begin{array}{l}\text { Nickel, } \\
\text { total } \\
\text { recov- } \\
\text { erable } \\
(\mu g / L \\
\text { as } N i)\end{array}$ \\
\hline \multicolumn{8}{|l|}{ Bedrock deposits--continued } \\
\hline $\begin{array}{l}\text { Prairie du Chien Group- } \\
\text { Trempealeau Formation }\end{array}$ & 30 & 33 & 17 & 20 & .20 & 3 & 1 \\
\hline Lake Superior sandstone & 30 & 29 & 40 & 40 & $<.50$ & 1 & 4 \\
\hline $\begin{array}{l}\text { Trempealeau-Munising } \\
\text { Formations }\end{array}$ & $<10$ & 8.2 & 30 & 30 & .10 & 2 & 1 \\
\hline Munising Formation & $<10$ & 18 & 15 & 20 & $<.10$ & 2 & 1 \\
\hline $\begin{array}{l}\text { Cambrian-Precambrian } \\
\text { rocks }\end{array}$ & $<10$ & 30 & 30 & 30 & $<.10$ & 1 & 2 \\
\hline Keweenawan Supergroup & $<10$ & 5.9 & $<1$ & $<10$ & $<.10$ & 1 & 2 \\
\hline Jacobsuille Sandstone & $<10$ & 8.0 & 6 & 6 & .15 & 2 & 6 \\
\hline Freda Sandstone & 55 & 7.2 & 2 & 36 & .20 & 2 & 3 \\
\hline $\begin{array}{l}\text { Copper Harbor } \\
\text { Conglomerate }\end{array}$ & 21 & 5.5 & 1 & $<10$ & $<.10$ & 2 & 4 \\
\hline Portage Lake Volcanics & $<10$ & .9 & 5 & $<10$ & $<.10$ & 2 & $<1$ \\
\hline Michigamne slate & 5 & 11 & 236 & 226 & $<.10$ & 10 & 2 \\
\hline Ironwood Iron-Formation & 10 & 18 & 3 & $<10$ & $<.10$ & $<1$ & $<1$ \\
\hline Randville Dolomite & $<10$ & 18 & 25 & 60 & .10 & 2 & 3 \\
\hline
\end{tabular}


Median values of chemical and physical characteristics of water from geologic sources--Continued

\begin{tabular}{|c|c|c|c|c|c|c|c|}
\hline & $\begin{array}{c}\text { Nitro- } \\
\text { gen, } \\
\text { total } \\
\text { (mg/L } \\
\text { as N) }\end{array}$ & $\begin{array}{c}\text { Nitro- } \\
\text { gen, } \\
\text { ammonia, } \\
\text { total } \\
\text { (mg/L } \\
\text { as N) }\end{array}$ & $\begin{array}{l}\text { Nitro- } \\
\text { gen, } \\
\text { nitrate, } \\
\text { total } \\
\text { (mg/L } \\
\text { as } N \text { ) }\end{array}$ & $\begin{array}{l}\text { Nitro- } \\
\text { gen, } \\
\text { nitrite, } \\
\text { total } \\
\text { (mg/L } \\
\text { as N) }\end{array}$ & $\begin{array}{c}\text { Nitro- } \\
\text { gen, } \\
\text { organic, } \\
\text { total } \\
(\mathrm{mg} / \mathrm{L} \\
\text { as } N)\end{array}$ & $\underset{\text { (units) }}{\mathrm{pH}}$ & $\begin{array}{c}\text { Phenols, } \\
\text { total } \\
(\mu g, L)\end{array}$ \\
\hline \multicolumn{8}{|l|}{ Glacial deposits } \\
\hline $\begin{array}{l}\text { Glacial deposits, } \\
\text { undifferentiated }\end{array}$ & 0.63 & 0.03 & 0.05 & $<0.01$ & 0.11 & 7.6 & $<1$ \\
\hline Gravel & .20 & .07 & .01 & $<.01$ & .08 & 7.8 & 0 \\
\hline Lakebeds & .30 & .03 & .07 & .03 & .17 & 8.0 & 4 \\
\hline Moraine & .24 & $<.01$ & .21 & $<.01$ & .03 & 8.0 & 0 \\
\hline Outwash & .36 & .04 & .02 & $<.01$ & .13 & 7.6 & 1 \\
\hline Sand & .42 & .02 & .02 & $<.01$ & .14 & 7.9 & 0 \\
\hline Sand and clay & .45 & $<.01$ & .28 & $<.01$ & .17 & 8.1 & 0 \\
\hline Sand and gravel & .31 & .08 & .02 & $<.01$ & .10 & 7.8 & 0 \\
\hline \multicolumn{8}{|l|}{ Bedrock deposits } \\
\hline Paleozoic dolomite & .15 & .08 & .00 & $<.01$ & .07 & 7.9 & 0 \\
\hline Pennsylvanian shale & .98 & .93 & .00 & .01 & .04 & 7.9 & 1 \\
\hline Pennsylvanian sandstone & .83 & .67 & .00 & $<.01$ & .16 & 7.9 & 0 \\
\hline Saginaw Formation & .80 & .54 & $<.01$ & $<.01$ & .25 & 7.6 & 2 \\
\hline Michigan Formation & .40 & .29 & .00 & .00 & .11 & 7.0 & 2 \\
\hline Marshall Formation & .24 & .07 & $<.10$ & $<.01$ & .04 & 7.6 & 1 \\
\hline Antrim Shale & .44 & .15 & .00 & .00 & .29 & 7.6 & 0 \\
\hline Traverse Group & .24 & .02 & $<.10$ & $<.01$ & .10 & 7.6 & 0 \\
\hline Dundee Formation & .60 & .38 & .05 & .01 & .16 & 7.6 & 3 \\
\hline Detroit River Group & 2.6 & .28 & $<.10$ & $<.01$ & 2.3 & 7.5 & 0 \\
\hline Sylvania Sandstone & .30 & .22 & $<.10$ & $<.01$ & .08 & 7.3 & 2 \\
\hline Bass Islands Dolomite & .62 & .44 & $<.10$ & $<.01$ & .16 & 7.1 & 3 \\
\hline Engãdine Dolomite & .42 & .14 & $<.10$ & $<.01$ & .25 & 7.8 & 2 \\
\hline Manistique Dolomite & .50 & .01 & $<.10$ & $<.01$ & .18 & 7.8 & 3 \\
\hline Burnt Bluff Formation & .14 & .08 & $<.10$ & $<.01$ & .11 & 7.5 & 2 \\
\hline Niagaran Series & $<.20$ & .05 & $<.10$ & $<.01$ & $<.01$ & 7.8 & 1 \\
\hline Ordovician, Upper & .26 & .19 & .01 & .00 & .06 & 7.8 & 0 \\
\hline Big Hill Limestone & .75 & .17 & .22 & $<.01$ & .36 & 7.8 & 0 \\
\hline Trenton Limestone & .13 & .06 & $<.10$ & $<.01$ & .05 & 7.6 & 2 \\
\hline $\begin{array}{l}\text { Trenton-Black River } \\
\text { Limestones }\end{array}$ & .21 & .08 & .04 & $<.01$ & .07 & 7.5 & 1 \\
\hline Black River Limestone & .45 & .13 & $<.10$ & .01 & .30 & 7.6 & 2 \\
\hline Mohawkian Series & .32 & .03 & .05 & $<.01$ & .24 & 7.8 & 1 \\
\hline Hermansville Limestone & .72 & .14 & $<.10$ & $<.01$ & .56 & 7.8 & 3 \\
\hline Prairie du Chien Group & 0.09 & 0.07 & $<0.10$ & $<0.01$ & 0.01 & 8.1 & $<1$ \\
\hline
\end{tabular}


Median values of chemical and physical characteristics of water from geologic sources--Continued

\begin{tabular}{|c|c|c|c|c|c|c|c|}
\hline & $\begin{array}{l}\text { Nitro- } \\
\text { gen, } \\
\text { total } \\
(\mathrm{mg} / \mathrm{L} \\
\text { as } N \text { ) }\end{array}$ & $\begin{array}{c}\text { Nitro- } \\
\text { gen, } \\
\text { ammonia, } \\
\text { total } \\
\text { (mg/L } \\
\text { as N) }\end{array}$ & $\begin{array}{l}\text { Nitro- } \\
\text { gen, } \\
\text { nitrate, } \\
\text { total } \\
\text { (mg/L } \\
\text { as } N \text { ) }\end{array}$ & $\begin{array}{l}\text { Nitro- } \\
\text { gen, } \\
\text { nitrite, } \\
\text { total } \\
\text { (mg/L } \\
\text { as } N)\end{array}$ & $\begin{array}{l}\text { Nitro- } \\
\text { gen, } \\
\text { organic, } \\
\text { total } \\
\text { (mg/L } \\
\text { as } N)\end{array}$ & $\underset{\text { (units) }}{\mathrm{pH}}$ & $\begin{array}{l}\text { Phenols, } \\
\text { total } \\
(\mu \mathrm{g} / \mathrm{L})\end{array}$ \\
\hline \multicolumn{8}{|l|}{ Bedrock deposits--continued } \\
\hline $\begin{array}{l}\text { Prairie du Chien Group- } \\
\text { Trempealeau Formation }\end{array}$ & .42 & .05 & $<.10$ & $<.01$ & .35 & 7.7 & 3 \\
\hline Lake Superior sandstone & .47 & .07 & .01 & $<.01$ & .39 & 7.8 & 0 \\
\hline $\begin{array}{l}\text { Trempealeau-Munising } \\
\text { Formations }\end{array}$ & .17 & .04 & $<.10$ & .00 & .07 & 7.7 & 2 \\
\hline Munising Formation & .05 & .04 & $<.10$ & $<.01$ & .01 & 8.0 & 1 \\
\hline $\begin{array}{l}\text { Cambrian-Precambrian } \\
\text { rocks }\end{array}$ & .22 & .08 & $<.10$ & $<.01$ & .12 & 7.9 & $<1$ \\
\hline Keweenawan supergroup & .32 & .01 & $<.10$ & $<.01$ & .29 & 7.7 & $<1$ \\
\hline Jacobsville Sandstone & .25 & $<.01$ & .12 & $<.01$ & .12 & 7.6 & 0 \\
\hline Freda Sandstone & .90 & $<.01$ & .65 & $<.01$ & .25 & 7.2 & 3 \\
\hline $\begin{array}{l}\text { Copper Harbor } \\
\text { Conglomerate }\end{array}$ & .28 & .02 & .25 & $<.01$ & .01 & 7.4 & 2 \\
\hline Portage Lake Volcanics & .05 & .03 & $<.10$ & $<.01$ & .01 & 8.8 & $<1$ \\
\hline Michigamme slate & .20 & .04 & .15 & $<.01$ & .01 & 7.6 & 2 \\
\hline Ironwood Iron-Formation & .24 & .03 & .20 & $<.01$ & .01 & 7.6 & $<1$ \\
\hline Randville Dolomite & .42 & .02 & $<.10$ & $<.01$ & .38 & 8.1 & 2 \\
\hline
\end{tabular}


Median values of chemical and physical characteristics of water from geologic sources--Continued

\begin{tabular}{|c|c|c|c|c|c|c|c|}
\hline & $\begin{array}{c}\text { Phos- } \\
\text { phorus, } \\
\text { total } \\
\text { (mg/L } \\
\text { as P) }\end{array}$ & $\begin{array}{l}\text { Phos- } \\
\text { phorus, } \\
\text { ortho, } \\
\text { total } \\
\text { (mg/L } \\
\text { as P) }\end{array}$ & $\begin{array}{l}\text { Potas- } \\
\text { sium, } \\
\text { dis- } \\
\text { solved } \\
\text { (mg/L } \\
\text { as K) }\end{array}$ & $\begin{array}{l}\text { Selenium, } \\
\text { total } \\
\text { ( } \mu g / L \\
\text { as Se) }\end{array}$ & $\begin{array}{l}\text { silica, } \\
\text { dis- } \\
\text { solved } \\
\text { (mg/L } \\
\text { as } \\
\text { sio }_{2} \text { ) }\end{array}$ & $\begin{array}{l}\text { Silver, } \\
\text { total } \\
\text { recov- } \\
\text { erable } \\
(\mu g / L \\
\text { as Ag) }\end{array}$ & $\begin{array}{l}\text { Sodium, } \\
\text { dis- } \\
\text { solved } \\
\text { (mg/L } \\
\text { as Na) }\end{array}$ \\
\hline \multicolumn{8}{|l|}{ Glacial deposits } \\
\hline $\begin{array}{l}\text { Glacial deposits, } \\
\text { undifferentiated }\end{array}$ & 0.02 & 0.01 & 1.2 & $<1$ & 12 & $<1$ & 9.0 \\
\hline Gravel & .02 & $<.01$ & 1.4 & $<1$ & 11 & $<1$ & 3.0 \\
\hline Lakebeds & .05 & .05 & .5 & $<1$ & 7.4 & $<1$ & 2.5 \\
\hline Moraine & .01 & $<.01$ & .9 & $<1$ & 15 & $<1$ & 1.9 \\
\hline Outwash & .01 & $<.01$ & .9 & $<1$ & 10 & $<1$ & 4.5 \\
\hline Sand & .01 & $<.01$ & .7 & $<1$ & 9.8 & $<1$ & 2.6 \\
\hline Sand and clay & .01 & .01 & 1.1 & $<1$ & 19 & $<1$ & 2.7 \\
\hline Sand and gravel & .01 & $<.01$ & .9 & $<1$ & 11 & $<1$ & 3.7 \\
\hline \multicolumn{8}{|l|}{ Bedrock deposits } \\
\hline Paleozoic dolomite & $<.01$ & $<.01$ & 1.4 & $<1$ & .9 & $<1$ & 7.4 \\
\hline Pennsylvanian shale & .01 & $<.01$ & 5.8 & $<1$ & 6.2 & $<1$ & 110 \\
\hline Pennsylvanian sandstone & $<.01$ & $<.01$ & 4.6 & $<1$ & 6.1 & $<2$ & 110 \\
\hline Saginaw Formation & .02 & $<.01$ & 6.4 & $<1$ & 10 & $<1$ & 400 \\
\hline Michigan Formation & .01 & .00 & 3.6 & 0 & 11 & 0 & 290 \\
\hline Marshall Formation & $<.01$ & $<.01$ & 2.0 & $<1$ & 12 & $<1$ & 19 \\
\hline Antrim Shale & .00 & .01 & 2.3 & 0 & 10 & 0 & 140 \\
\hline Traverse Group & .01 & $<.01$ & 2.1 & $<1$ & 8.8 & $<1$ & 3.9 \\
\hline Dundee Formation & $<.01$ & $<.01$ & 1.8 & $<1$ & 15 & $<1$ & 24 \\
\hline Detroit River Group & .02 & .01 & 2.4 & $<1$ & 20 & $<1$ & 20 \\
\hline Sylvania Sandstone & .02 & $<.01$ & 1.9 & $<1$ & 14 & $<1$ & 23 \\
\hline Bass Islands Dolomite & $<.01$ & $<.01$ & 2.6 & $<1$ & 13 & $<1$ & 6.0 \\
\hline Engadine Dolomite & .04 & .21 & 2.0 & $<1$ & 12 & $<1$ & 19 \\
\hline Manistique Dolomite & $<.01$ & $<.01$ & .8 & $<1$ & 6.7 & $<1$ & 1.9 \\
\hline Burnt Bluff Formation & .01 & .01 & 1.6 & $<1$ & 6.5 & $<1$ & 2.4 \\
\hline Niagaran Series & .02 & $<.01$ & 2.5 & $<1$ & 8.5 & $<1$ & 8.4 \\
\hline Ordovician, Upper & .01 & .00 & 14 & 0 & 8.2 & 0 & 97 \\
\hline Big Hill Limestone & .04 & .01 & 9.0 & $<1$ & .6 & $<1$ & 160 \\
\hline Trenton Limestone & .07 & $<.01$ & 2.1 & $<1$ & 18 & $<1$ & 6.4 \\
\hline $\begin{array}{l}\text { Trenton-Black River } \\
\text { Limestones }\end{array}$ & $<.01$ & $<.01$ & 2.0 & $<1$ & 12 & $<1$ & 6.2 \\
\hline Black River Limestone & .02 & .02 & 3.8 & $<1$ & 9.6 & $<1$ & 14 \\
\hline Mohawkian Series & $<.01$ & $<.01$ & 2.0 & $<1$ & 7.8 & $<1$ & 2.0 \\
\hline Hermansville Iimestone & $<.01$ & $<.01$ & 1.5 & $<1$ & 17 & $<1$ & 2.3 \\
\hline Prairie du Chien Group & 0.01 & $<0.01$ & 3.2 & $<1$ & 7.4 & $<1$ & 4.6 \\
\hline
\end{tabular}


Median values of chemical and physical characteristics of water from geologic sources--Continued

\begin{tabular}{|c|c|c|c|c|c|c|c|}
\hline & $\begin{array}{l}\text { Phos- } \\
\text { phorus, } \\
\text { total } \\
(\mathrm{mg} / \mathrm{L} \\
\text { as P) }\end{array}$ & $\begin{array}{l}\text { Phos- } \\
\text { phorus, } \\
\text { ortho, } \\
\text { total } \\
\text { (mg/L } \\
\text { as P) }\end{array}$ & $\begin{array}{l}\text { Potas- } \\
\text { sium, } \\
\text { dis- } \\
\text { solved } \\
\text { (mg/L } \\
\text { as } K \text { ) }\end{array}$ & $\begin{array}{l}\text { Selenium, } \\
\text { total } \\
(\mu g / L \\
\text { as K) }\end{array}$ & $\begin{array}{c}\text { silica, } \\
\text { dis- } \\
\text { solved } \\
\text { (mg/L } \\
\text { as } \\
\mathrm{siO}_{2} \text { ) }\end{array}$ & $\begin{array}{l}\text { silver, } \\
\text { total } \\
\text { recov- } \\
\text { erable } \\
\text { ( } \mu g / L \\
\text { as Ag) }\end{array}$ & $\begin{array}{l}\text { Sodium, } \\
\text { dis- } \\
\text { solved } \\
\text { (mg/L } \\
\text { as } \mathrm{Na} \text { ) }\end{array}$ \\
\hline \multicolumn{8}{|l|}{ Bedrock deposits-continued } \\
\hline $\begin{array}{l}\text { Prairie du Chien Group- } \\
\text { Trempealeau Formation }\end{array}$ & .01 & $<.01$ & 4.1 & $<1$ & 6.9 & 1 & 34 \\
\hline Lake Superior sandstone & $<.01$ & $<.01$ & 5.4 & $<1$ & 7.4 & $<1$ & 65 \\
\hline $\begin{array}{l}\text { Trempealeau-Munising } \\
\text { Formations }\end{array}$ & .01 & .01 & 2.0 & 0 & 13 & 0 & 3.6 \\
\hline Munising Formation & .01 & $<.01$ & 2.6 & $<1$ & 8.9 & $<1$ & 3.2 \\
\hline $\begin{array}{l}\text { Cambrian-Precambrian } \\
\text { rocks }\end{array}$ & $<.01$ & $<.01$ & 1.7 & $<1$ & 20 & $<1$ & 4.0 \\
\hline Keweenawan Supergroup & -- & $<.01$ & .5 & $<1$ & 18 & $<1$ & 22 \\
\hline Jacobsville Sandstone & .01 & .01 & 1.8 & $<1$ & 12 & $<1$ & 7.0 \\
\hline Freda Sandstone & .08 & .04 & 4.1 & $<1$ & 18 & $<1$ & 30 \\
\hline $\begin{array}{l}\text { Copper Harbor } \\
\text { Conglomerate }\end{array}$ & .02 & $<.01$ & .7 & $<1$ & 8.4 & $<1$ & 15 \\
\hline Portage Lake Volcanics & $<.01$ & $<.01$ & .1 & $<1$ & 15 & $<1$ & 34 \\
\hline Michigamme Slate & $<.01$ & $<.01$ & 1.0 & 1 & 16 & $<1$ & 3.1 \\
\hline Ironwood Iron-Formation & .02 & .01 & 1.3 & 10 & 13 & $<1$ & 9.8 \\
\hline Randville Dolomite & .03 & $<.01$ & 1.3 & $<1$ & 5.7 & $<1$ & 1.3 \\
\hline
\end{tabular}


Median values of chemical and physical characteristics of water from geologic sources--Continued

\begin{tabular}{|c|c|c|c|c|c|c|c|}
\hline & $\begin{array}{l}\text { Solids, } \\
\text { residue } \\
\text { at } 180 \\
\text { deg. C } \\
\text { dis- } \\
\text { solved } \\
(\mathrm{mg} / \mathrm{L})\end{array}$ & $\begin{array}{l}\text { Solids, } \\
\text { sum of } \\
\text { consti- } \\
\text { tuents, } \\
\text { dis- } \\
\text { solved } \\
(\mathrm{mg} / \mathrm{L})\end{array}$ & $\begin{array}{c}\text { Specific } \\
\text { conductance } \\
\text { (microsiemens) }\end{array}$ & $\begin{array}{l}\text { Stron- } \\
\text { tium, } \\
\text { total } \\
\text { recov- } \\
\text { erable } \\
\text { ( } \mu g / L \\
\text { as } S r)\end{array}$ & $\begin{array}{l}\text { Sulfate } \\
\text { dis- } \\
\text { solved } \\
\text { (mg/L } \\
\text { as } \mathrm{SO}_{4} \text { ) }\end{array}$ & $\begin{array}{c}\text { Temper- } \\
\text { ature } \\
\text { (deg. C) }\end{array}$ & $\begin{array}{l}\text { Tin, } \\
\text { total } \\
\text { recov- } \\
\text { erable } \\
(\mu g / L \\
\text { as } S n)\end{array}$ \\
\hline \multicolumn{8}{|l|}{ Glacial deposits } \\
\hline $\begin{array}{l}\text { Glacial deposits, } \\
\text { undifferentiated }\end{array}$ & 249 & 239 & 408 & 130 & 14 & 9.5 & $<2$ \\
\hline Gravel & 137 & 169 & 289 & 120 & 7.8 & 8.5 & $<2$ \\
\hline Lakebeds & 138 & 133 & 240 & 60 & 12 & 8.5 & -- \\
\hline Moraine & 115 & 108 & 167 & 70 & 8.3 & 7.0 & -- \\
\hline Outwash & 206 & 200 & 408 & 100 & 11 & 9.5 & $<10$ \\
\hline Sand & 182 & 188 & 324 & 75 & 11 & 9.0 & $<3$ \\
\hline Sand and clay & 183 & 168 & 280 & 60 & 7.9 & 7.5 & -- \\
\hline Sand and gravel & 160 & 160 & 254 & 90 & 10 & 9.0 & -- \\
\hline \multicolumn{8}{|l|}{ Bedrock deposits } \\
\hline Paleozoic dolomite & 291 & 282 & 482 & 3,600 & 57 & 7.5 & -- \\
\hline Pennsylvanian shale & 614 & 612 & 880 & 1,000 & 320 & 9.5 & -- \\
\hline Pennsylvanian sandstone & 438 & 444 & 735 & 700 & 64 & 10.0 & -- \\
\hline Saginaw Formation & 1,260 & 1,210 & 1,540 & 1,700 & 40 & 11.0 & $<10$ \\
\hline Michigan Formation & 1,320 & 1,220 & 2,410 & 1,800 & 200 & 22.0 & -- \\
\hline Marshall Formation & 362 & 336 & 609 & 580 & 40 & 10.0 & -- \\
\hline Antrim Shale & 439 & 434 & 777 & 410 & .90 & 8.5 & -- \\
\hline Traverse Group & 340 & 324 & 593 & 370 & 28 & 9.0 & -- \\
\hline Dundee Formation & 421 & 654 & 614 & 13,000 & 150 & 12.0 & -- \\
\hline Detroit River Group & 536 & 253 & 628 & 39,000 & 38 & 11.0 & -- \\
\hline Sylvania Sandstone & 670 & 780 & 920 & 15,000 & 230 & 13.5 & -- \\
\hline Bass Islands Dolomite & 1,970 & 1,870 & 2,190 & 12,000 & 1,200 & 12.0 & -- \\
\hline Engadine Dolomite & 794 & 743 & 947 & 5,080 & 460 & 8.0 & -- \\
\hline Manistique Dolomite & 245 & 238 & 413 & 100 & 11 & 8.0 & -- \\
\hline Burnt Bluff Formation & 358 & 338 & 584 & 180 & 14 & 9.5 & -- \\
\hline Niagaran Series & 353 & 376 & 643 & 16,000 & 140 & 10.5 & -- \\
\hline Ordovician, Upper & -- & 667 & 1,140 & 4,900 & 60 & 13.0 & -- \\
\hline Big Hill Limestone & 1,820 & 1,540 & 2,200 & 2,500 & 750 & 9.0 & - \\
\hline Trenton Limestone & 253 & 275 & 472 & 125 & 18 & 9.0 & -- \\
\hline $\begin{array}{l}\text { Trenton-Black River } \\
\text { Limestones }\end{array}$ & 385 & 332 & 612 & 170 & 45 & 9.5 & -- \\
\hline Black River Limestone & 339 & 402 & 725 & 725 & 50 & 10.0 & -- \\
\hline Mohawkian Series & 197 & 202 & 380 & 250 & 10 & 8.0 & -- \\
\hline Hermansville Limestone & 249 & 227 & 416 & 120 & 7.5 & 8.5 & -- \\
\hline Prairie du Chien Group & 156 & 167 & 295 & 370 & 14 & 7.5 & -- \\
\hline
\end{tabular}


Median values of chemical and physical characteristics of water from geologic sources--Continued

\begin{tabular}{|c|c|c|c|c|c|c|c|}
\hline & $\begin{array}{l}\text { Solids, } \\
\text { residue } \\
\text { at } 180 \\
\text { deg. C } \\
\text { dis- } \\
\text { solved } \\
(\mathrm{mg} / \mathrm{L})\end{array}$ & $\begin{array}{l}\text { Solids, } \\
\text { sum of } \\
\text { consti- } \\
\text { tuents, } \\
\text { dis- } \\
\text { solved } \\
(\mathrm{mg} / \mathrm{L})\end{array}$ & $\begin{array}{c}\text { Specific } \\
\text { conductance } \\
\text { (microsiemens) }\end{array}$ & $\begin{array}{l}\text { Stron- } \\
\text { tium, } \\
\text { total } \\
\text { recov- } \\
\text { erable } \\
(\mu g / L \\
\text { as Sr) }\end{array}$ & $\begin{array}{l}\text { Sulfate } \\
\text { dis- } \\
\text { solved } \\
\text { (mg/L } \\
\left.\text { as } \mathrm{SO}_{4}\right)\end{array}$ & $\begin{array}{c}\text { Temper- } \\
\text { ature } \\
\text { (deg. C) }\end{array}$ & $\begin{array}{l}\text { Tin, } \\
\text { total } \\
\text { recov- } \\
\text { erable } \\
\text { ( } \mu \mathrm{g} / \mathrm{L} \\
\text { as } \mathrm{Sn})\end{array}$ \\
\hline \multicolumn{8}{|l|}{ Bedrock deposits--continued } \\
\hline $\begin{array}{l}\text { Prairie du Chien Group- } \\
\text { Trempealeau Formation }\end{array}$ & 300 & 296 & 1,080 & 860 & 55 & 12.0 & -- \\
\hline Lake Superior sandstone & 532 & 478 & 905 & 1,300 & 44 & 13.0 & -- \\
\hline $\begin{array}{l}\text { Trempealeau-Munising } \\
\text { Formations }\end{array}$ & 252 & 261 & 272 & 160 & 13 & 8.5 & -- \\
\hline Munising Formation & 226 & 243 & 415 & 120 & 27 & 13.0 & -- \\
\hline $\begin{array}{l}\text { Cambrian-Precambrian } \\
\text { rocks }\end{array}$ & 238 & 249 & 432 & 180 & 18 & 7.0 & -- \\
\hline Keweenawan Supergroup & 161 & 163 & 262 & 100 & 7.3 & 10.0 & -- \\
\hline Jacobsville Sandstone & 158 & 152 & 274 & 200 & 5.8 & 9.0 & -- \\
\hline Freda Sandstone & 200 & 183 & 336 & 400 & 12 & 8.2 & -- \\
\hline $\begin{array}{l}\text { Copper Harbor } \\
\text { Conglomerate }\end{array}$ & 176 & 172 & 306 & 130 & 5.3 & 7.0 & -- \\
\hline Portage Lake Volcanics & 155 & 153 & 278 & 50 & 5.5 & 9.0 & -- \\
\hline Michigamme Slate & 159 & 156 & 262 & 100 & 26 & 9.0 & -- \\
\hline Ironwood Iron-Formation & 212 & 209 & 379 & 140 & 6.3 & 10.0 & -- \\
\hline Randville Dolomite & $\bullet 170$ & 168 & 327 & 2,600 & 9.0 & 7.0 & -- \\
\hline
\end{tabular}


Median values of chemical and physical characteristics of water from geologic sources--Continued

\begin{tabular}{|c|c|c|c|c|c|c|c|}
\hline & $\begin{array}{l}\text { Tita- } \\
\text { nium, } \\
\text { total } \\
\text { ( } \mu \mathrm{g} / \mathrm{L} \\
\text { as Ti) }\end{array}$ & $\begin{array}{l}\text { Tritium, } \\
\text { total } \\
(\mathrm{pCi} / \mathrm{L})\end{array}$ & $\begin{array}{c}\text { Turbid- } \\
\text { ity } \\
\text { (FTU) }\end{array}$ & $\begin{array}{c}\text { Uranium, } \\
\text { dis- } \\
\text { solved, } \\
\text { extrac- } \\
\text { tion } \\
(\mu g / L \\
\text { as } U)\end{array}$ & $\begin{array}{c}\text { Vanadium, } \\
\text { total } \\
(\mu g / L \\
\text { as V) }\end{array}$ & $\begin{array}{l}\text { Zinc, } \\
\text { total } \\
\text { recov- } \\
\text { erable } \\
(\mu g / L \\
\text { as } Z n)\end{array}$ & $\begin{array}{l}\mathrm{z} \text { ircon- } \\
\text { i um, } \\
\text { totai } \\
(\mu \mathrm{g} / \mathrm{L} \\
\text { as } \mathrm{zr})\end{array}$ \\
\hline \multicolumn{8}{|l|}{ Glacial deposits } \\
\hline $\begin{array}{l}\text { Glacial deposits, } \\
\text { undifferentiated }\end{array}$ & $<2$ & $<200$ & 2.4 & 0.18 & $<10$ & 15 & $<4$ \\
\hline Gravel & 14 & $<200$ & .65 & .25 & 5 & 105 & $<4$ \\
\hline Lakebeds & -- & $<200$ & 5.5 & .57 & 2 & 20 & -- \\
\hline Moraine & -- & $\rightarrow$ & -- & -- & -- & 120 & -- \\
\hline Outwash & $<10$ & $<200$ & .75 & .22 & $<1$ & 45 & $<30$ \\
\hline Sand & $<20$ & $<200$ & .20 & .11 & $<10$ & 110 & $<6$ \\
\hline Sand and clay & -- & -- & -- & -- & -- & 210 & -- \\
\hline Sand and gravel & - & 35 & 15 & $<.03$ & $<1$ & 90 & -- \\
\hline \multicolumn{8}{|l|}{ Bedrock deposits } \\
\hline Paleozoic dolomite & -- & -- & -- & -- & -- & 240 & -- \\
\hline Pennsylvanian shale & -- & -- & -- & .01 & -- & 20 & -- \\
\hline Pennsylvanian sandstone & -- & -- & -- & .54 & -- & $<20$ & -- \\
\hline Saginaw Formation & $<30$ & $<200$ & 9.2 & .08 & 1 & 300 & $<50$ \\
\hline Michigan Formation & - & -- & 7.5 & .11 & 0 & 20 & -- \\
\hline Marshall Formation & $\rightarrow$ & $<200$ & 1.2 & .04 & 5 & 30 & -- \\
\hline Antrim Shale & -- & -- & 210 & .13 & 0 & 130 & -- \\
\hline Traverse Group & -- & $<200$ & 4.6 & .22 & $<10$ & 30 & -- \\
\hline Dundee Formation & $-\infty$ & $<24$ & 6.0 & $<.01$ & 4 & 35 & -- \\
\hline Detroit River Group & -- & 19 & 1.0 & .06 & $<1$ & 30 & -- \\
\hline Sylvania Sandstone & -- & 61 & 8.5 & .25 & $<1$ & 500 & -- \\
\hline Bass Islands Dolomite & -- & $<10$ & .2 & $<.01$ & $<1$ & 80 & -- \\
\hline Engadine Dolomite & -- & 133 & 14 & .02 & 5 & 850 & -- \\
\hline Manistique Dolomite & -- & $<120$ & .4 & -- & 1 & 40 & -- \\
\hline Burnt Bluff Formation & -- & $<100$ & 2.9 & .20 & $<10$ & 260 & -- \\
\hline Niagaran Series & -- & $<10$ & 3.5 & .02 & $<1$ & 110 & -- \\
\hline Ordovician, Upper & -- & - & 1.6 & .10 & 0 & 120 & $\rightarrow$ \\
\hline Big Hill Limestone & -- & -- & $-\infty$ & -- & -- & 4,700 & -- \\
\hline Trenton Limestone & - & 110 & 29 & 1.0 & $<1$ & 1,100 & -- \\
\hline $\begin{array}{l}\text { Trenton-Black River } \\
\text { Limestones }\end{array}$ & $\rightarrow$ & 83 & 1.5 & 2.7 & $<1$ & .95 & -- \\
\hline Black River Limestone & -- & $<100$ & .2 & .15 & 5 & 180 & -- \\
\hline Mohawkian Series & -- & -- & -- & $\rightarrow$ & -- & 100 & -- \\
\hline Hermansville Limestone & -- & $<26$ & .7 & -- & 2 & $<10$ & $-\rightarrow$ \\
\hline Prairie du Chiein Group & -- & 13 & 0.5 & 0.15 & -- & $<1$ & 20 \\
\hline
\end{tabular}


Median values of chemical and physical characteristics of water from geologic sources--Continued

\begin{tabular}{|c|c|c|c|c|c|c|c|}
\hline & $\begin{array}{l}\text { Tita- } \\
\text { nium, } \\
\text { total } \\
\text { ( } \mu g / L \\
\text { as Ti) }\end{array}$ & $\begin{array}{l}\text { Tritium, } \\
\text { total } \\
\text { (pci/I) }\end{array}$ & $\begin{array}{c}\text { Turbid- } \\
\text { ity } \\
\text { (FTU) }\end{array}$ & $\begin{array}{c}\text { Uranium, } \\
\text { dis- } \\
\text { solved, } \\
\text { extrac- } \\
\text { tion } \\
(\mu g / L \\
\text { as U) }\end{array}$ & $\begin{array}{c}\text { Vanadium, } \\
\text { total } \\
(\mu g / L \\
\text { as V) }\end{array}$ & $\begin{array}{l}\text { zinc, } \\
\text { total } \\
\text { recov- } \\
\text { erable } \\
(\mu g / L \\
\text { as } z n)\end{array}$ & $\begin{array}{l}\text { Zircon- } \\
\text { ium, } \\
\text { totai } \\
\text { ( } \mu g / I \\
\text { as } z r \text { ) }\end{array}$ \\
\hline \multicolumn{8}{|l|}{ Bedrock deposits--continued } \\
\hline $\begin{array}{l}\text { Prairie du Chien Group- } \\
\text { Trempealeau Formation }\end{array}$ & -- & 80 & 2.9 & .22 & $<1$ & 20 & -- \\
\hline Lake Superior sandstone & -- & -- & -- & -- & -- & 20 & -- \\
\hline $\begin{array}{l}\text { Trempealeau-Munising } \\
\text { Formations }\end{array}$ & -- & 21 & .5 & .10 & 0 & 60 & -- \\
\hline Munising Formation & -- & $<200$ & .6 & .10 & $<10$ & 100 & -- \\
\hline $\begin{array}{l}\text { Cambrian-Precambrian } \\
\text { rocks }\end{array}$ & -- & 16 & 1.5 & .03 & $<1$ & 540 & -- \\
\hline Keweenawan Supergroup & -- & 77 & .2 & -- & 4 & $<10$ & -- \\
\hline Jacobsville Sandstone & -- & 26 & .2 & 2.2 & 3 & 50 & -- \\
\hline Freda Sandstone & -- & 51 & 22 & -- & 8 & 35 & -- \\
\hline $\begin{array}{l}\text { Copper Harbor } \\
\text { Conglomerate }\end{array}$ & -- & 90 & 2.2 & 2.2 & 17 & 520 & -- \\
\hline Portage Lake Volcanics & -- & $<26$ & 1.8 & .72 & 1 & 50 & -- \\
\hline Michigamme slate & -- & 44 & 3.0 & .79 & 1 & 1,990 & -- \\
\hline Ironwood Iron-Formation & -- & 160 & .2 & .33 & $<1$ & 50 & -- \\
\hline Randville Dolomite & -- & 32 & 3.3 & -- & 1 & 680 & -- \\
\hline
\end{tabular}

